\title{
Chapter 12 \\ Economics of Land Degradation and Improvement in Bhutan
}

\author{
Ephraim Nkonya, Raghavan Srinivasan, Weston Anderson \\ and Edward Kato
}

\begin{abstract}
This study was conducted with the objective of determining the returns to sustainable land management (SLM) at the national level in Bhutan. The study first uses satellite data on land change (Landsat) to examine land use change in 1990-2010 and its impact on sediment loading in hydroelectric power plants. The study then uses the Soil and Water Assessment Tool (SWAT) model to analyze the impact of land use change and land management on sediment loading. The results from the land use change and SWAT analyses are used to assess the economic benefits of SLM. We estimate the benefits and costs of SLM practices and compare them with the land-degrading practices that are most prevalent in Bhutan-that is, business as usual. An analysis of the drivers of adoption of SLM practices is also done to draw conclusions about strategies that Bhutan could use to enhance adoption of SLM practices. The land cover change results show that the vast majority of forested areas remained as such between 1994 and 2010. SWAT results show that with long-term SLM practices such as contouring, increased forested cover and density, terracing, and other SLM practices, soil erosion from forested area could be reduced by $50 \%$. Analysis of returns to SLM practices showed that citrus orchards are the most profitable enterprises in 13 of the 20 districts (dzongkhag), but they require farmers to wait for at least six years before the first harvest. Improved pasture management is the second most profitable enterpriseunderscoring the potential role it can play to meet the growing demand for livestock products as household incomes increase. Returns to community forest management are low but profitable at a $10 \%$ discount rate. Considering the drivers of SLM
\end{abstract}

\author{
E. Nkonya $(\varangle) \cdot$ E. Kato \\ International Food Policy Research Institute, 2033 K Street NW, \\ Washington DC 20006, USA \\ e-mail: e.nkonya@cgiar.org \\ R. Srinivasan \\ Departments of Ecosystem Sciences and Management and Biological and Agricultural \\ Engineering, Texas A\&M University, College Station, Texas, TX 77843, USA \\ W. Anderson \\ Department of Earth \& Environmental Science Lamont-Doherty Earth Observatory, \\ Columbia University, 61 Route 9W, Palisades, NY 10964, USA \\ (C) The Author(s) 2016 \\ E. Nkonya et al. (eds.), Economics of Land Degradation \\ and Improvement - A Global Assessment for Sustainable Development, \\ DOI 10.1007/978-3-319-19168-3_12
}


adoption, our research shows an inverse relationship between returns to land management and their corresponding adoption rates. The factors that increase adoption of SLM were land security, access to extension services, and roads. In summary, Bhutan's policies and its cultural and historical background have set the country on the path to becoming a global green growth success story. Results of this study vindicate the country's efforts to invest in sustainable land and forest management and highlight the additional policies and strategies that will enhance achievement of Bhutan's SLM objectives.

Keywords Sustainable land management - Bhutan - Soil and water assessment tool $\cdot$ Hydroelectric power $\cdot$ Sediment

\section{Introduction and Context}

Bhutan's economy is dominated by hydroelectric power (HEP) generation - a sector that contributes about $22 \%$ of the country's gross domestic product (GDP), which makes HEP the largest sector (NSB 2009). Sediment loading leads to significant cost for most HEP plants in the world (IPCC 2012), relating to power generation loss, reduction of turbine efficiency and lifetime, and increased repair costs (Lysne et al. 2003). This underscores the role played by sustainable land management (SLM) in Bhutan, whose economy heavily depends on the HEP sector. In addition, about $69.1 \%$ of the population of 733,033 live in rural areas and depends on agriculture - a sector that contributed only $17 \%$ of the GDP in 2013 (NSB 2013). Crops - excluding horticultural crops-account for only $7.7 \%$ of the land area, whereas pasture and horticulture, respectively, account for 3.9 and $0.1 \%$ (Ministry of Agriculture 1995; currently Ministry of Agriculture and Forests [MoAF]).

Forests-which cover $70 \%$ of the land area-contributed only about $6.9 \%$ of Bhutan's GDP in 2010, but this contribution was from only timber and paper products (Food and Agriculture Organization of the United Nations [FAO] 2011). The value of non-timber forest products (NTFP) — including regulating and supporting ecosystem services - is much greater. Unlike in other countries, Forest and Nature Conservation Acts and Rules (NCD 2003) allow communities currently living in protected areas (PAs) to continue living in PAs on the condition that they observe key rules and regulations (Choden et al. 2010; Phuntsho et al. 2011). Our study estimates that at least $25 \%$ of Bhutan's population lives in PAs. The PAs comprise $19,751 \mathrm{~km}^{2}$, which is more than $51 \%$ of the land area of $38,394 \mathrm{~km}^{2}$, a level that only a few countries have achieved (MoAF 2010). This suggests that the PAs provide abundant ecosystem services to the population living both inside and outside PAs. The PAs also serve as the catchment and source of rivers supplying water to HEP plants. Out of the four major HEP plants of Bhutan, the sources of water for Chhukha, Kurichhu, and Tala HEP come from the PAs. 
This study was undertaken with the objective of assessing the economic benefits of SLM in clear monetary terms and conducting a national-level cost-benefit assessment of investments into SLM. Results of the study will be used to design Bhutan's SLM strategies to achieve its 2020 Vision of Peace, Prosperity and Happiness of the Bhutanese people by enhancing their traditional values and improving their standard of living and environmental sustainability (RGoB 2002). Based on the economic analysis, the study would also identify priority investments with the highest economic benefits for the country. Furthermore, the analysis will allow the Royal Government of Bhutan (RGoB) to mainstream SLM in its five-year plan's programs and provide budgetary support on a priority basis.

The next section summarizes Bhutan's opportunities and challenges related to SLM. A brief discussion about the study background and approach is provided to set the stage for subsequent sections. This is followed by a discussion of Bhutan's land cover change trends and major biophysical characteristics. Analysis of soil erosion using the SWAT model follows the Land Use Change section. Using data collected by the renewable natural resource (RNR) household survey conducted in 2009, the study then analyzes land management practices and the drivers of adoption of SLM practices. This is followed by the economic analysis of the SLM practices at a national level. The final section concludes the study and gives policy implications.

\section{Bhutan's Opportunities and Challenges Related to Sustainable Land Management}

\section{Opportunities}

- Bhutan's mountains provide immense opportunities for HEP. The HEP sector currently accounts for up to $40 \%$ of government revenue (DGPC 2009) and has the potential to grow. Owing to the large quantity of suitable terrain, the currently installed capacity of $1488 \mathrm{mw}$ is only about $5 \%$ of the estimated total HEP potential. Bhutan's vision is to achieve $10,000 \mathrm{mw}$ installed capacity by 2020 (DGPC 2009).

- The large area under cover provides local benefits-including serving as a source of water used for HEP generation-and global benefits of carbon sequestration, biodiversity, genetic information, and other forest ecosystems. Such services provide opportunities for Bhutan to derive payment for ecosystem services from the global community.

- Bhutan's deep-rooted traditions and its cultural values of Mahayana Buddhism serve as a robust cultural foundation for realizing the benefits of sustainable development. It is these cultural values, which stress the co-existence of people with nature and the sanctity of life, compassion for others, and happiness in general, that led Bhutan to adopt the Gross National Happiness measure instead of the traditional GDP. However, given that Bhutan's economy is heavily 
dependent on natural resources, these cultural values also have been contributing to the long-term economic welfare of the Bhutanese people by encouraging sustainable development as Bhutan works toward its 2020 Vision of Peace, Prosperity and Happiness.

\section{Challenges}

- Only $30 \%$ of the population uses inorganic fertilizer, and $60 \%$ uses manure. As a result of this and other challenges, yields of maize and rice are only about 67 and $50 \%$ of the potential yield (Chetri et al. 2003).

- Bhutan's forest development policy from 1961 to the 1980 s followed centrally managed and industrial forest harvesting, which eroded community responsibility for forest management and subsequently led to forest degradation (Gyamtsho et al. 2006). In response to this, a royal decree in 1979 and the Forest and Nature Conservation Act in 1995, among other statutes, gave communities a mandate to practice CFM) (Gyamtsho et al. 2006; Phuntsho et al. 2011). In 2010, fewer than 300 CFM systems existed, and it is expected that the total number of community forests (CFs) will reach only 400 by 2013, covering a negligible $4 \%$ of the total forest area. The total forest area appropriate for CFM is $2380 \mathrm{~km}^{2}$, or $20 \%$ of forest area managed by the central government (Phuntsho et al. 2011). The slow pace of CFM adoption poses a challenge to ensuring sustainable forest management (SFM).

- Significant soil erosion leads to high repair costs of HEP plants. DGPC spends US\$16 million each year to repair turbines and other underwater structures due to sediment loading. About $60 \%$ of such cost is associated with sediment loading.

- Bhutan's topography makes land management and transportation infrastructure development a challenge. Road and other market infrastructure development is costlier and could trigger more severe soil erosion than is the case in flatter landscapes. About $30 \%$ of Bhutan's population lives in areas from which it takes more than three hours to walk to the nearest motor-road (RGoB, MoAF 2010a, b).

\section{Study Background and Approach}

There are many definitions of SLM, and each emphasizes some elements of two key issues: long-term maintenance of ecosystem services and provision of ecosystem services desired by people (Winslow et al. 2011). The World Overview of Conservation Approaches and Technologies (WOCAT) defines SLM as the use of land resources for the production of goods and services to meet changing human 
needs while simultaneously ensuring the long-term productive potential of land resources and the maintenance of their environmental functions (WOCAT 2007). However, the United Nations Convention to Combat Desertification (UNCCD) defines SLM as "land managed in such a way as to maintain or improve ecosystem services for human wellbeing, as negotiated by all stakeholders" (Winslow et al. 2011). The element of desired functions is context specific since human needs differ significantly. One type of land management practice may be viewed as land degrading in one part of the world but as SLM in another. So our working definition will be in the context of Bhutan's needs according to 2020 Vision: "Peace, Prosperity and Happiness of the Bhutanese people by enhancing their traditional values, improving their standard of living and environmental sustainability" (RGoB 2002). For RGoB to be able to achieve such a goal, our analysis will look at both on-farm and off-site benefits of SLM practices and the costs and benefits of land-degrading management practices. In this study, the primary off-site benefit of SLM considered is the reduction of sediment, which has large benefits to HEP plants. The SWAT model results will be used to determine the impact of SLM on sediment loading.

SLM - as used in this study - does not necessarily mean complete prevention of land degradation or complete rehabilitation of degraded lands. A land management practice will be regarded as SLM if it completely or partially prevents or reduces land degradation. This could apply to land management that may still be causing a reduced form of land degradation but is better than the prevailing land-degrading practices. For example, the amount of chemical fertilizer applied may be less than the amount required to fully replenish soil nutrients taken up by crops but is regarded as SLM if it is better than the prevailing land-degrading practice. However, to ensure that we reflect Bhutan's desired function and needs, a land management practice is regarded as sustainable if it is undertaken according to the country's recommended practices. For cropland, the recommended soil fertility management practices and crop varieties will be regarded as SLM. Improved pasture management is regarded as SLM for livestock management. Likewise, the country's effort to promote CFM is regarded as SLM for the relevant and available forested area.

Responding to Bhutan's desired functions, our SLM analysis will focus on HEP, forest, livestock, and agricultural land management. Given the large data needs required for determining the on-farm and off-farm benefits of SLM, our study will rely heavily on existing data and studies. The study will also use the SWAT simulation model to assess the short- and long-term impacts of management practices on the watersheds. This approach will allow us to determine the off-site impact of upstream SLM practices on sediment loading in HEP.

The study was motivated by an SLM project that was funded by the Global Environment Facility (GEF) under the World Bank's administration. The main objective of the SLM project-which ended in June 2013 - was to protect vulnerable land and to rehabilitate degraded lands. Table 12.1 summarizes SLM project's major activities and their expected outcomes. 
Table 12.1 Prevention of land degradation and rehabilitation of degraded lands by sustainable land management project

\begin{tabular}{|c|c|c|}
\hline $\begin{array}{l}\text { Sustainable land } \\
\text { management project }\end{array}$ & $\begin{array}{l}\text { Area } \\
\text { covered (ha) }\end{array}$ & Expected major outcome \\
\hline $\begin{array}{l}\text { Protection of } \\
\text { vulnerable lands }\end{array}$ & 2410 & \\
\hline - Bamboo plantation & 296 & $\begin{array}{l}\text { Bamboo planted in rills gullies to reduce gully } \\
\text { formation }\end{array}$ \\
\hline $\begin{array}{l}\text { - Community and } \\
\text { private forest }\end{array}$ & 1422 & $\begin{array}{l}\text { Sustainable timber production, protection and use of } \\
\text { natural forests and water resources, and rehabilitation of } \\
\text { barren area through plantation }\end{array}$ \\
\hline - Check dams & $937^{\mathrm{a}}$ & $\begin{array}{l}\text { Water conservation and availability through water } \\
\text { source protection }\end{array}$ \\
\hline $\begin{array}{l}\text { - Planting leguminous } \\
\text { crops }\end{array}$ & 141 & Improved soil fertility through nitrogen fixation \\
\hline - Other & 17 & \\
\hline Stonewalling/bunding & & Prevention/reduction of soil erosion \\
\hline $\begin{array}{l}\text { - Rehabilitation of } \\
\text { degraded lands }\end{array}$ & 2573 & $\begin{array}{l}\text { Conversion of slash-and-burn agriculture practice (ex- } \\
\text { tseri land) to more sustainable land use }\end{array}$ \\
\hline - Dryland terracing & 45 & $\begin{array}{l}\text { This involves conversion of steep-sloped land to } \\
\text { terraced land that is used for irrigated crops (chhuzhing) } \\
\text { if irrigation water is available }\end{array}$ \\
\hline - Wetland terracing & 49 & $\begin{array}{l}\text { Terracing irrigated areas (wetlands) to reduce soil } \\
\text { erosion }\end{array}$ \\
\hline - Contour & 157 & Reduced soil erosion \\
\hline - Hedgerow & 326 & Reduced soil erosion \\
\hline - Agroforestry & 39 & Reduced soil erosion, nitrogen fixation \\
\hline - Orchard plantation & 833 & $\begin{array}{l}\text { Planting of fruit trees on steep dry land previously used } \\
\text { as tseri or allowed to lie fallow, generate income for } \\
\text { fruit sales }\end{array}$ \\
\hline - Annual crops & 1126 & Income generation \\
\hline $\begin{array}{l}\text { - Manure shed } \\
\text { construction }\end{array}$ & & $\begin{array}{l}\text { Reduction of forest degradation and soil erosion by } \\
\text { reducing number of stray grazing animals, increase crop } \\
\text { yield through use of farm yard manure, increase milk } \\
\text { production }\end{array}$ \\
\hline
\end{tabular}

Source GEF (2012)

Note: tseri shifting cultivation/slash-and-burn cultivation; chhuzhing wetlands

${ }^{a}$ Number of check dams constructed

Just as in the SLM project, our study will focus on land management practices that prevent land degradation and those that rehabilitate degraded lands. However, our study was conducted at a national level and will move beyond SLM project's focus on agricultural land. The focus will be on the three land use types-forests, cropland, and grazing lands. We will focus on selected land management practices 
that are the most commonly used. The discussion for each of the major land use types gives its corresponding economic importance and land area coverage.

\section{Forest}

Forest contributed about $24 \%$ of the agricultural GDP in 2000-2009 and grew at a modest average of $1.7 \%$ during the same time (Christensen et al. 2012). About $70.5 \%$ of the land area in Bhutan is covered with forests (RGoB, MoAF 2010a, b), and the constitution states that forest cover should be at least $60 \%$ of the total land area (RGoB 2008). The small contribution of forest to GDP is due to the nonvaluation of other ecosystem services provided by forests. As discussed earlier, rivers supplying HEP originate from forests, but the water catchment, prevention of soil erosion, and other roles of the forests are not taken into account when computing GDP.

The RGoB has realized the importance of decentralizing forest management and has encouraged communities to manage the forest resources to meet their forest needs. As of 2012, 21,723 rural households - or $24 \%$ of all rural householdsmanaged CF, which covered 62,237 ha or $1.8 \%$ of forested area (Dukra 2013). There are two ways that more households could participate in CF programs: (1) converting centrally managed government forest reserve to CF and (2) converting unused lands to CF. As shown in Table 12.2 , only about $4000 \mathrm{~km}^{2}$ is available for $\mathrm{CF}$. The government had estimated that the $\mathrm{CF}$ area would account for $4 \%$ of the total forested area by 2013 (RGoB, MoAF 2010a, b), but only $1.8 \%$ of the forested area was CF by 2012 (Dukra 2013).

SFM can be achieved in part by reforesting cleared lands and by increasing forest density of degraded forests. As shown below, only a small area experienced deforestation. But there is large potential for improvement of forest density through better management, which could be achieved through decentralization of public forest to $\mathrm{CF}$ management.

Table 12.2 Available area for community forest in Bhutan

\begin{tabular}{l|l|l}
\hline Sustainable land management project & $\begin{array}{l}\text { Area } \\
\left(\mathrm{km}^{2}\right)\end{array}$ & $\begin{array}{l}\text { Estimated impact on forest } \\
\text { ecosystem services (\% change) }\end{array}$ \\
\hline $\begin{array}{l}\text { Convert centrally managed non-protected area } \\
\text { forests to community forests }\end{array}$ & $3974.3^{\mathrm{a}}$ & 25 \\
\hline $\begin{array}{l}\text { Convert unused lands to community forest } \\
\left(\mathrm{km}^{2}\right)\end{array}$ & $2.4^{\mathrm{b}}$ & \\
\hline
\end{tabular}

Source Ministry of Agriculture and Forests data (2010)

Note: $\mathrm{km}^{2}$ square kilometers. ${ }^{\text {a }}$ Total forest area $\left(27,053.0 \mathrm{~km}^{2}\right)$ - protected area $\left(19,751.0 \mathrm{~km}^{2}\right)$ community forests $\left(622.4 \mathrm{~km}^{2}\right)$-government forest reserve $\left(2705.3 \mathrm{~km}^{2}\right)=3974.3 \mathrm{~km}^{2}$. ${ }^{\mathrm{b}}$ Unused land: agriculture to fallow, bushland, or bare land $(2.17)+$ unused land $(0.17)+$ deforested area $(0.02)=2.36 \mathrm{~km}^{2}$ 


\section{Crops and Citrus}

The contribution of the major cereal crops (rice, maize, barley, and wheat) to the agricultural GDP has declined significantly since 2007 (Christensen et al. 2012). One of the reasons for such decline is land degradation. We focus our analysis on maize and rice, which, respectively, account for 42 and $52 \%$ of the cultivated crop area. We also analyze fruit crops, which occupy a small land area yet form the largest cash income of the rural households and dominate the commercial agriculture for both domestic and export markets. Thirteen out of 20 districts (dzongkhag) are major growers of citrus (mainly mandarin orange) (MoAF 2011).

Maize Maize contributed $17 \%$ of the crop GDP in 2009 (Christensen et al. 2012), but $69 \%$ of farmers in BhutanBhutan grow maize, and the crop accounts for $49 \%$ of the food basket and $42 \%$ of the cultivated area (Tobgay and McCullough 2008). Cultivated mainly in the eastern region of the country, maize is the second most important food crop in Bhutan after rice (Tobgay and McCullough 2008).

Rice Paddy rice contributed $23.3 \%$ of the crop GDP in 2009 (Christensen et al. 2012) - the largest contribution, shared with citrus. Rice production occupied 59,609 ha or $52 \%$ of the cultivated area of 112,550 ha in 2010 (RGoB, MoAF 2012). The crop is mainly irrigated and grown in the warmer areas in the mid-altitude and low-altitude areas. Rice is an important staple crop, and its demand is growing, putting pressure on domestic production.

Fruit and horticultural crops Citrus production contributed $73.6 \%$ of the crop GDP growth in 2000-2009 (Christensen et al. 2012) and $66 \%$ of the household cash income. Fruit production has increased faster than production of cereals due to fruit's high returns and increasing demand. Fruit and horticultural crops are grown mainly during the summer period and are grown in the following agroecological zones (AEZs): warm temperate, dry subtropical, humid subtropical, and wet subtropical.

The SLM practice to be analyzed for maize and rice production is integrated soil fertility management (ISFM), which entails the use of organic inputs, judicious amounts of chemical fertilizer, and improved seeds (Vanlauwe and Giller 2006). The ISM matches the manure shed construction done by the SLM project to increase the production and use of farm yard manure. Studies in Bhutan have shown that ISFM significantly increases yields of rice and maize (Chetri et al. 2003). ISFM is used since it performs better than the use of mineral fertilizer or organic input alone (Vanlauwe and Giller 2006; Nandwa and Bekunda 1998).

\section{Livestock}

Livestock accounted for about $28 \%$ of the agricultural GDP from 2000 to 2009 and grew at an average of $2.7 \%$ during the same period (Christensen et al. 2012). 
Two-thirds of rural households own cattle; most have two or more head of cattle (NSB and AsDB 2013). Livestock ownership is inversely related to consumption quintile. About $78 \%$ of households in the poorest quintile and $18 \%$ of the richest quintile own cattle (NSB and AsDB 2013). However, in the rural areas, $82 \%$ of the poorest quintile and $44 \%$ of the richest quintile own cattle (NSB and AsDB 2013).

The grazing area covers $11 \%$ of the land area (Wangdi 2006), which is greater than the cropland area. The SLM practice that will be used is improved pasture, which could lead to both prevention of soil erosion and greater livestock productivity. Improved pasture includes planting leguminous seeds, improved grasses such as cocksfoot, and Italian rye and lotus (Samdup et al. 2013; Dorji 1993). Improved pasture also includes rotational grazing on rangelands, which allows pasture to recover (Chophyel 2009). Rearing of few improved breeds in lieu of large numbers of local breeds to reduce pressure on resources is encouraged.

\section{Methodological Analysis and Data}

To achieve a national-level SLM analysis, we will rely heavily on existing data and on simulation modeling to analyze SLM and its economic impact. The first aspect to analyze is land use change, which will help determine the potential impact on sediment loading. The effect of land use change on sediment loading will be analyzed using SWAT model simulation. The SWAT modeling will also include SLM practices beyond land use changes, including those that could affect sediment loading, for example, using SWM practices on cropland to reduce soil erosion. The economic analysis will include all results to determine the returns to all SLM practices.

\section{Land Use Change}

To measure the accuracy of and consistency between records of land cover, we use two datasets to analyze land use change:

\section{Landsat Land Cover Dataset, Covering the 1990-2010 Period}

The 30 meter (m) 30-m resolution data were derived from Landsat ETM + Satellite imagery and evaluated using Advanced Land Observation Satellite imagery and Google Earth. The data were harmonized and standardized by the International Center for Integrated Mountain Development in collaboration with the Bhutanese Ministry of Agriculture and Forests. 


\section{Bhutan Land Cover Assessment, Covering the 1994-2010 Period}

The data sources, classification, and methods differed between the data collected in 1994 and that collected in 2010, which makes computation of land use change less reliable. The 1994 data were obtained from Panchromatic (black-and-white photographic film) images and were processed manually to delineate land use types. The 2010 data were obtained from Advanced Land Observation Satellite (AVNIR-2) images with a 10-m resolution. Unlike the 1994 dataset, the 2010 dataset was rigorously conducted with extensive ground truthing, an aspect missing from the Landsat dataset.

An analysis of the 2010 Landsat and 2010 national land cover datasets demonstrated that they compare favorably in their classification of agriculture, urban area, forested area, shrubland, and grassland. The comparison lends considerable credibility to the Landsat dataset, which was not ground-thruthed in the same rigorous manner as was the national land cover dataset. The moderate differences in the grassland/shrubland classes and more pronounced differences in snow cover and barren land may be explained in part by seasonality. The season in which the satellite images were taken will strongly influence the advance/retreat of the snowpack, grassland, and shrubland in the northern regions of Bhutan.

The decision about which land cover dataset - if not both - to use in the land cover change detection was based on the intended purpose of each dataset. The documentation for the national land cover dataset states explicitly that the dataset is not intended to be used in a change analysis given the methodological advances between the two datasets. But the Landsat-derived dataset produced all three years of coverage simultaneously with the express purpose of maintaining consistency in the methodology. While the Landsat dataset does have validation shortcomings (discussed previously), the consistency between years makes it ideal for land cover change analysis. In the case of pastureland, however, the Landsat dataset does not distinguish between grassland/shrubland and pastureland. For calculation of pastureland expansion and contraction the national dataset was used. These results should be interpreted keeping in mind the change in classification methods between 1994 and 2010.

\section{Soil Erosion Analysis}

\section{Study Area}

The total drainage area of the 11 river basins in Bhutan is approximately $47,541 \mathrm{~km}^{2}$. The northern region of Bhutan consists of glaciated mountain peaks, with the highest elevations more than $7000 \mathrm{~m}$ above sea level. In the south, the southern foothills are covered with dense, deciduous forests; alluvial lowland river valleys; and mountains up to $1500 \mathrm{~m}$ above sea level (Fig. 12.1). 


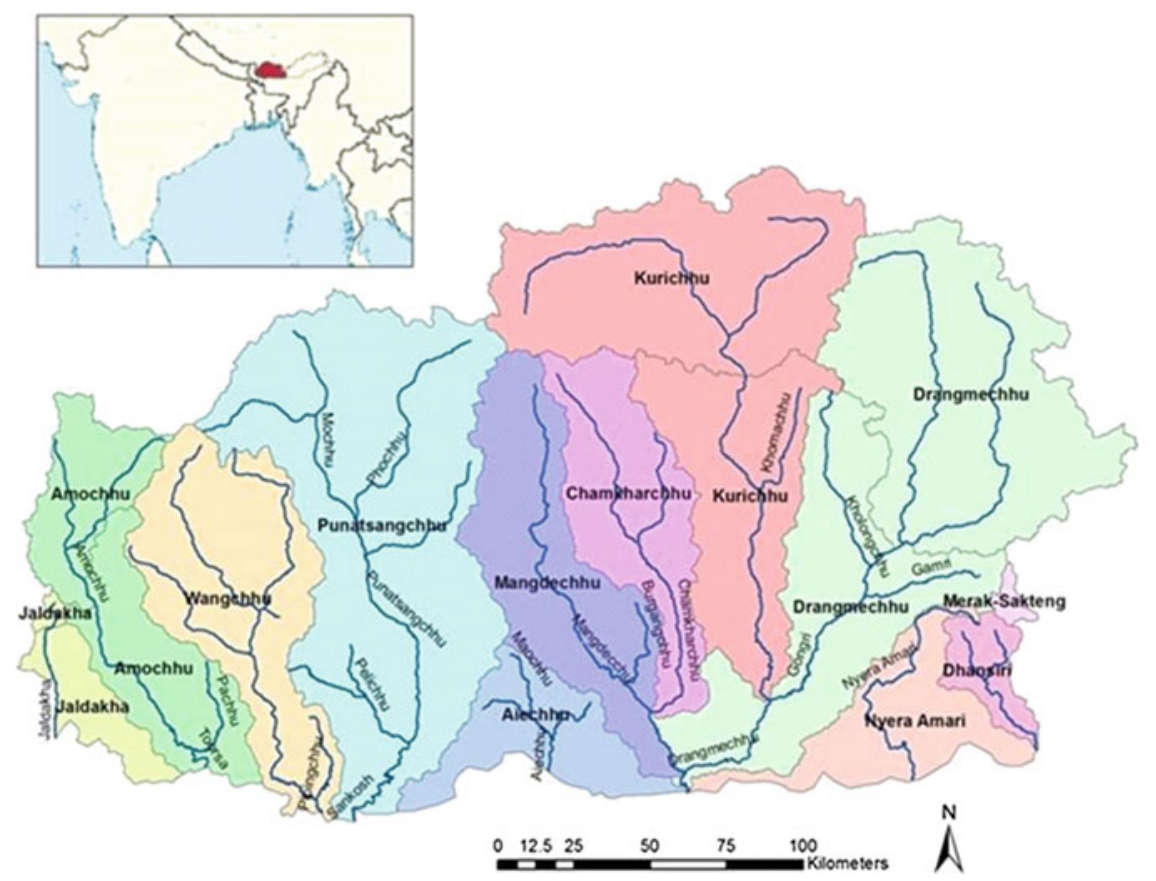

Fig. 12.1 Main rivers and major river basins. Source Ministry of Agriculture and Forests data (2013)

According to the United Nations Environment Programme (2009), Bhutan can be divided into three climatic zones: subtropical zone in the southern foothills with high humidity and heavy rainfall between 2500 and $5550 \mathrm{~mm}$ per year; temperate zone in the highlands with cool winters and hot summers, rising to $3000 \mathrm{~m}$; and alpine climate zone under perpetual snow, with elevations up to $7550 \mathrm{~m}$ and average annual precipitation of $400 \mathrm{~mm}$. Bhutan's water resources are confined to four major river basins: Amo Chhu, Wang Chhu, Puna-Tsang Chhu, and Manas Chhu. They all originate from the high-altitude alpine area and from the perpetual snow cover in the north and flow into the Brahmaputra River in the Indian plains.

\section{SWAT}

SWAT (Arnold et al. 1998) is a physically based, continuous simulation model developed to assess the short- and long-term impacts of management practices on large watersheds. The model requires extensive input data, which can be supplemented using internal model databases and algorithms for generating synthetic weather data (Luzio et al. 2002). The model divides watersheds into a number of sub-basins and adopts the concept of the hydrologic response unit (HRU), which is delineated according to a number of key parameters, such as land use, soil, and 


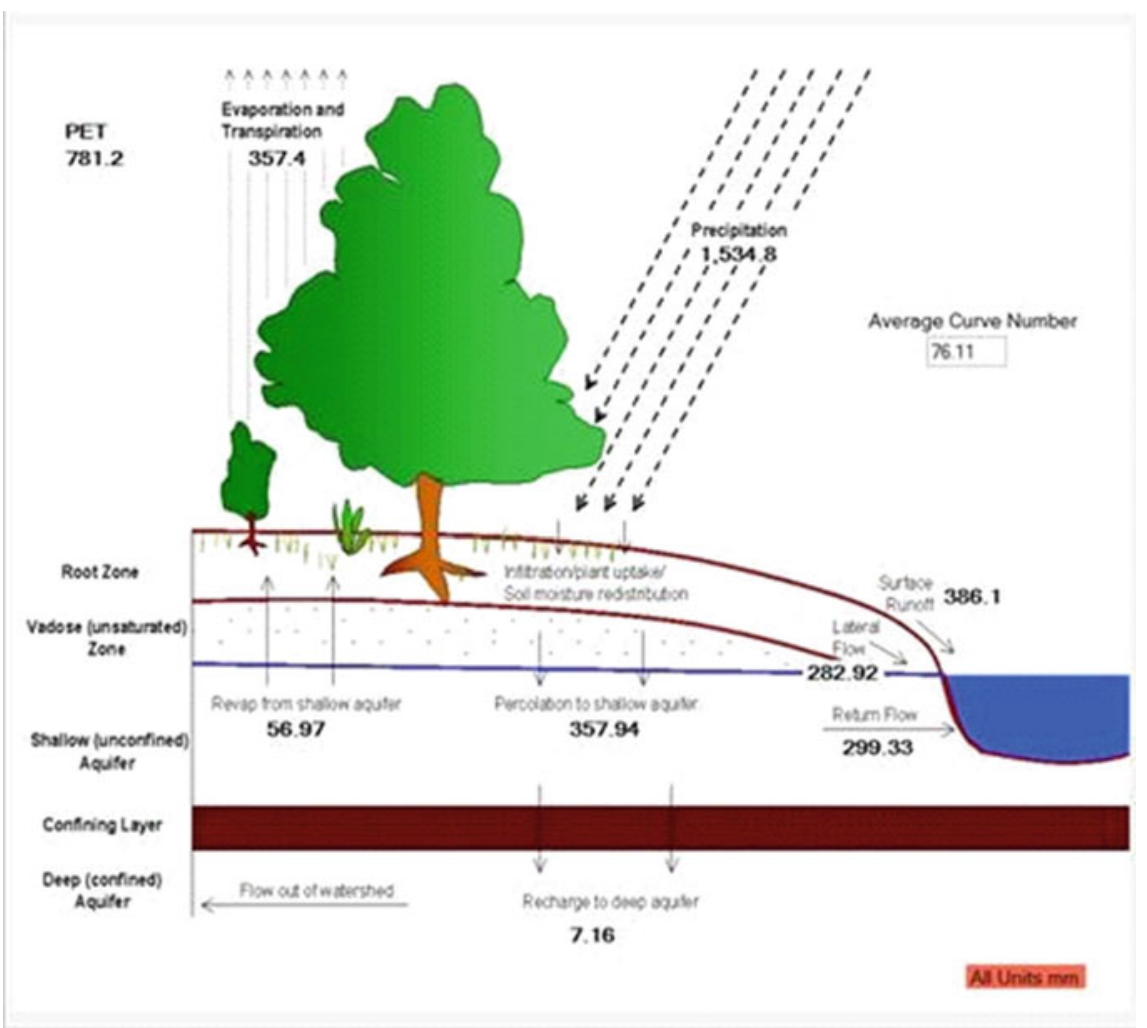

Fig. 12.2 Hydrologic budget of the basin from SWAT-check. Source Authors. Note: SWAT soil and water assessment tool; PET potential evapotranspiration; $\mathrm{mm}$ millimeters

slope. SWAT is able to simulate rainfall-runoff based on separate HRUs, which are aggregated to generate output from each sub-basin. SWAT is a combination of modules for water flow and balance, sediment transport, vegetation growth, nutrient cycling, and weather generation. SWAT can establish various scenarios detailed by different climate, soil, and land cover as well as the schedule of agricultural activities including crop planting, tillage, and best management practices (Flay 2001). A schematic presentation of SWAT hydrological modeling is presented in Fig. 12.2.

In summary, the benefits of using SWAT for this project are that, first, SWAT offers finer spatial and temporal scales, which allow the user to observe an output at a particular sub-basin on a particular day. Second, it considers comprehensive hydrological processes, estimating not only surface runoff with associated sediment and nutrients but also groundwater flow and channel processes within each sub-basin and at the watershed scale. However, nutrients were not modeled as part of this study. Third, on completion of this study, the calibrated model can be 
developed to further analyze scenarios such as best management practices, land use changes, climate change, and more.

\section{Data Required for SWAT Analysis}

Elevation (digital elevation model DEM) The National Soil Services Center (NSSC) provided DEM data with 10-meter resolution. The DEM was used to automatically delineate watershed boundaries and channel networks. Elevation ranges from 22 to $7456 \mathrm{~m}$ (Fig. 12.3). Steep area (slope of more than $63 \%$ ) accounts for $42.9 \%$ of the area, whereas less than $6 \%$ of the area is flat with slopes of $0-2 \%$.

Land use NSSC provided the land cover dataset created in 2010 (Fig. 12.4). Percentages of each land cover are summarized in Table 12.3. However, as seen above, Landsat land cover datasets were also used to analyze land use change. For 2010 , land use types consist primarily of pine $(55.35 \%)$ and cool-season grass $(17.91 \%)$. Concerning land use change, there are more than 600 glaciers in Bhutan with an area of approximately $1300 \mathrm{~km}^{2}$ (Beldring and Voksø 2011). There is an increasing tendency to go for cash crops such as apples in the temperate north and oranges in the subtropical south (Wangdi 2006).

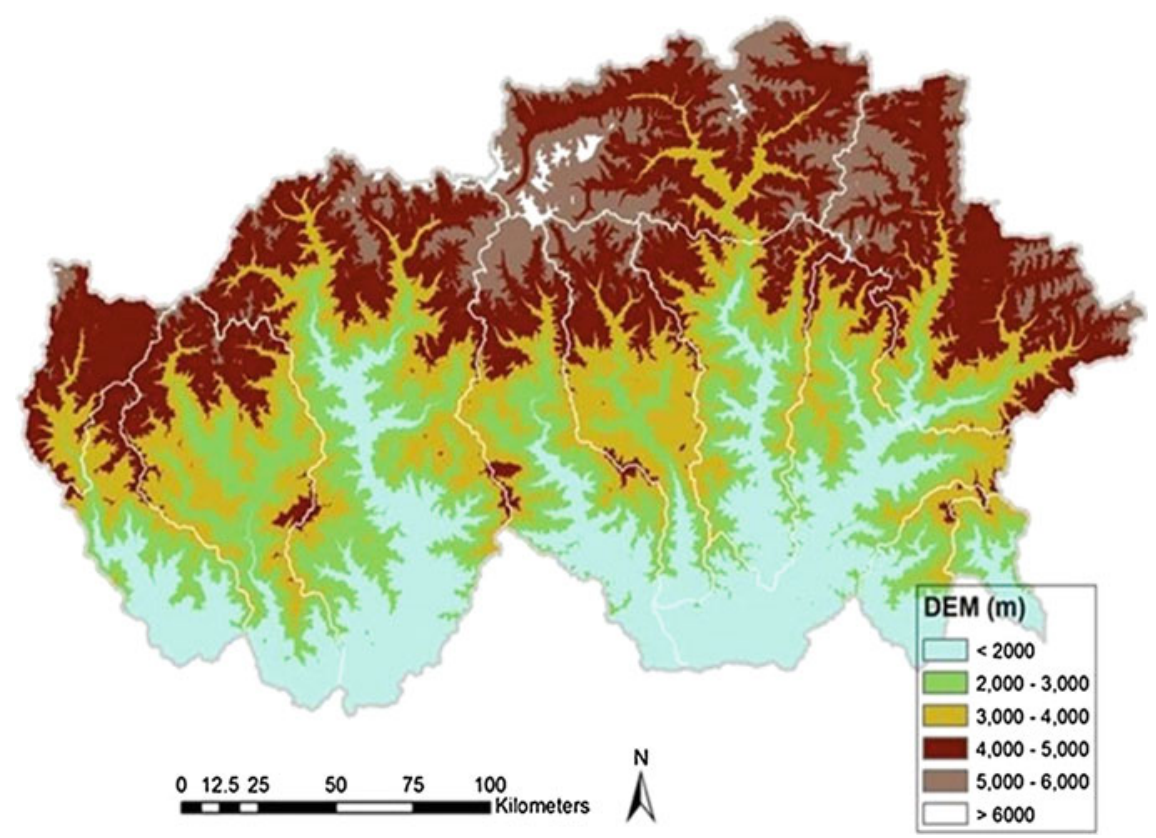

Fig. 12.3 DEM of for the country of Bhutan at 10-meter resolution. Source National Soil Services Center data (2013). Note: DEM digital elevation model; $m$ meters 


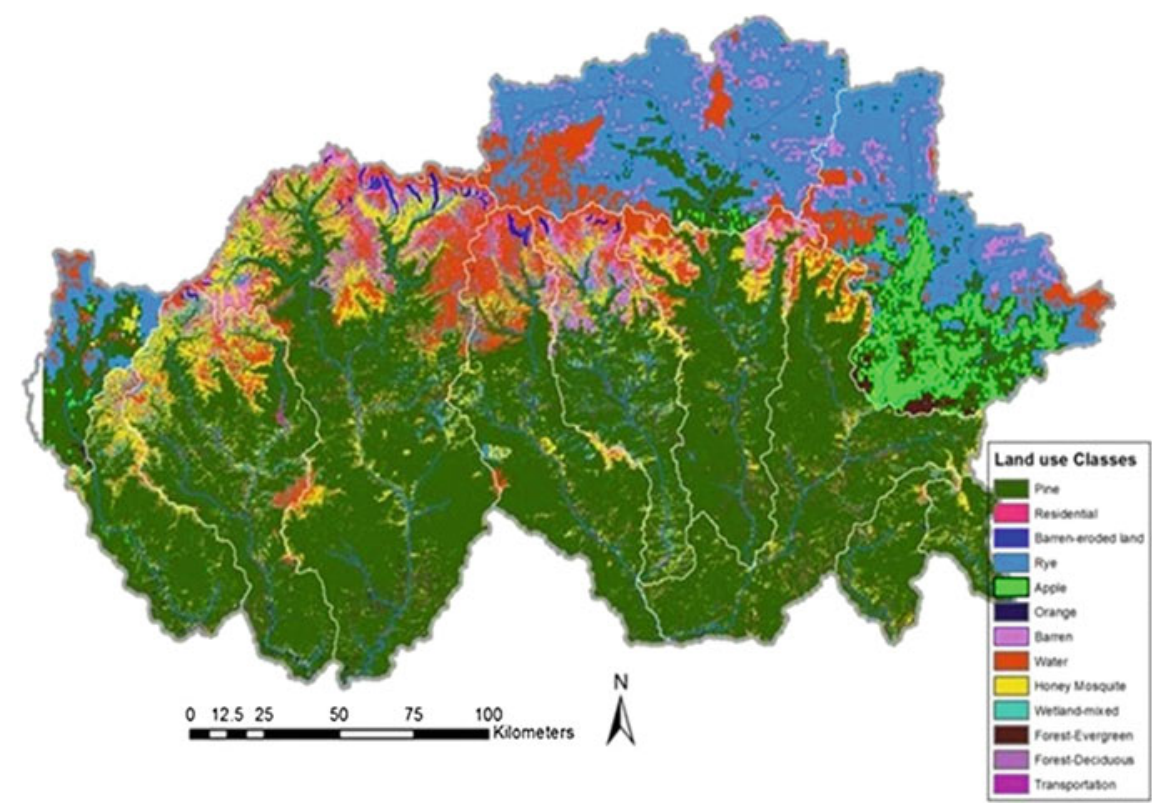

Fig. 12.4 Bhutan national land cover dataset (30-meter resolution) created in 2010. Source National Soil Services Center data (2010)

Table 12.3 Land use categories determined by the national land cover dataset (2010)

\begin{tabular}{l|c}
\hline Land use type & Percentage of watershed area \\
\hline Pine & 55.35 \\
\hline Residential & 0.08 \\
\hline Barren-eroded land & 0.38 \\
\hline Natural grassland & 17.91 \\
\hline Apple & 2.56 \\
\hline Orange & 0.08 \\
\hline Barren & 4.31 \\
\hline Water & 10.03 \\
\hline Honey mesquite & 8.42 \\
\hline Wetlands-mixed & 0.01 \\
\hline Forest-evergreen & 0.39 \\
\hline Transportation & 0.48 \\
\hline Total & 100.00
\end{tabular}

Source National Soil Services Center data (2010)

Soil FAO/UNESCO provided soil data in shape file format and converted it to GRID format at a 1:5,000,000 scale (Fig. 12.5). The FAO/UNESCO soil map (FAO/UNESCO 1977) classified about $27 \%$ of Bhutan as having either cambisols 


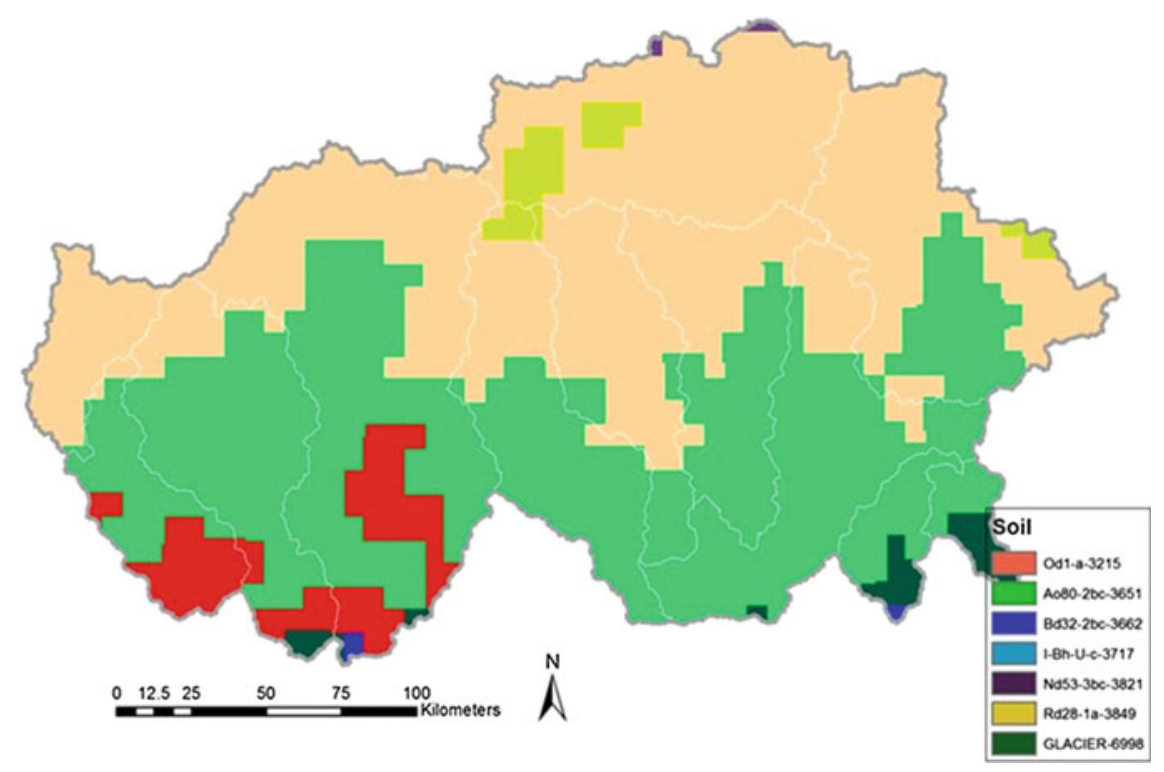

Fig. 12.5 FAO/UNESCO soil map of Bhutan. Source FAO/UNESCO (1977). Note Legend references FAO soil type codes. Od1-a-3215: Dystric Histosols, Ao80-2bc-3651: Orthic Acrisols, Bd32-2bc-3662: Dystric Cambisols, I-Bh-U-c-3717: Lithosols-Humic Cambisols-Rankers, Nd53-3bc-3821: Dystric Nitosols, Rd28-1a-3849: Dystric Regosols, GLACIER-6998: Glacier

or fluvisols (cambisols are most common in the medium-altitude zone, and fluvisols mostly occur in the southern belt). Less fertile acrisols, ferrasols, and podzols were estimated to cover $45 \%$ of the country. The same study also reports that $21 \%$ of the soil-covered area suffers from shallow depth with mostly lithosol occurring on steep slopes (Roder et al. 2001).

Weather stations The Hydromet department provided daily precipitation and temperature (minimum and maximum) data within and near the watershed from 1996 to 2012 (Table 12.4 and Fig. 12.6). A total of 20 local weather stations were used in this study (Fig. 12.7). The National Centers for Environmental Prediction's Climate Forecast System Reanalysis provided daily wind speed, relative humidity, and solar data in SWAT file format with $\sim 31 \mathrm{~km}$ horizontal and $\sim 35 \mathrm{~km}$ vertical resolution from 1979 through 2010.

Streamflow gauging stations Hydromet provided flow data at stream gauging stations, 24 of which were available in the basin (Fig. 12.8). Of those stations, 20 were used for modeling. All other stations were eliminated either because they had too much missing data or the gauging stations were located in a minor tributary and could not be analyzed. Table 12.5 summarizes the available gauging stations. 
Table 12.4 Local precipitation and temperature stations throughout and near the basin

\begin{tabular}{l|l|l|l}
\hline Name & Latitude & Longitude & Elevation \\
\hline Simtokha & 27.44 & 89.68 & 2310 \\
\hline Paro & 27.38 & 89.42 & 2406 \\
\hline Haa & 27.39 & 89.28 & 2711 \\
\hline Punakha & 27.58 & 89.86 & 1239 \\
\hline Gasakhatey & 27.96 & 89.73 & 2760 \\
\hline Wangdue & 27.49 & 89.90 & 1214 \\
\hline Trongsa & 27.50 & 90.51 & 2195 \\
\hline Zhemgang & 27.22 & 90.66 & 1862 \\
\hline Mongar & 27.28 & 91.26 & 1597 \\
\hline Lhuentse & 27.66 & 91.18 & 1430 \\
\hline Phuntsholing & 26.86 & 89.39 & 280 \\
\hline Sipsu & 28.51 & 89.54 & 423 \\
\hline Bhur & 28.27 & 88.87 & 377 \\
\hline Damphu & 27.50 & 90.55 & 1564 \\
\hline Dagana & 27.96 & 89.86 & 1865 \\
\hline Deothang & 26.86 & 91.46 & 861 \\
\hline PemaGatshel & 27.34 & 91.43 & 1723 \\
\hline TrashiYangtse & 27.61 & 91.50 & 1839 \\
\hline Kanglung & 27.28 & 91.52 & 2005 \\
\hline Bumthang & 27.55 & 90.72 & 3032 \\
\hline Sourc Hyd & & &
\end{tabular}

Source Hydromet data (2013)

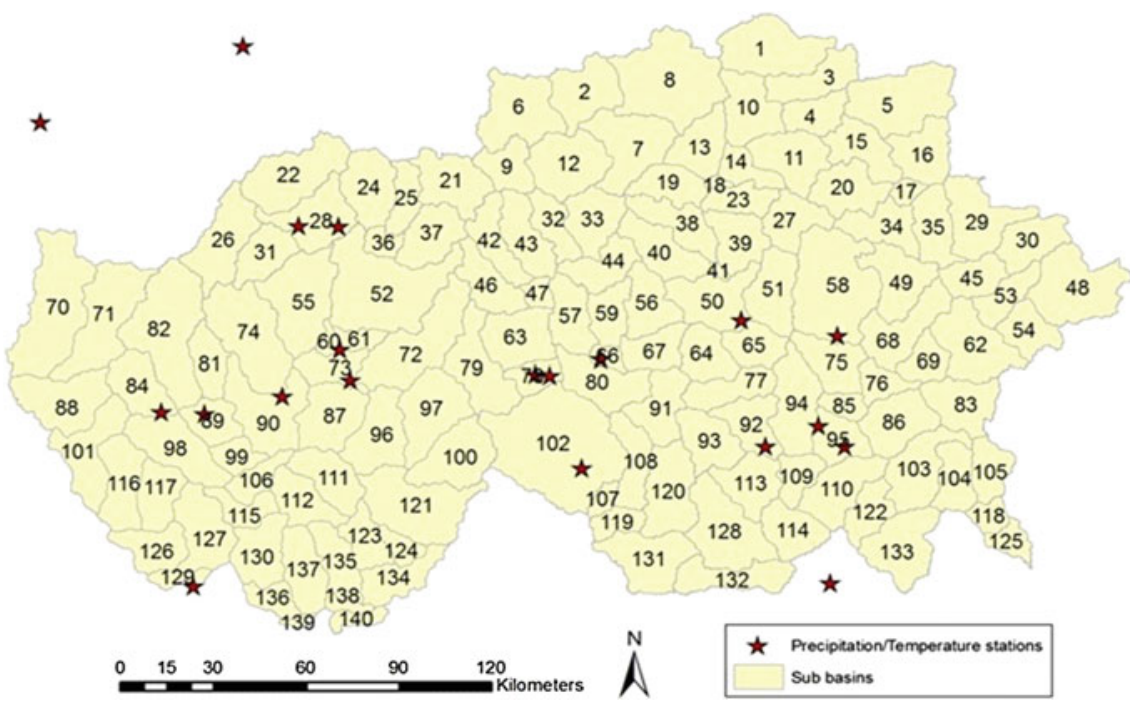

Fig. 12.6 Local precipitation and temperature stations throughout and near the basin. Source Hydromet data (2013) 


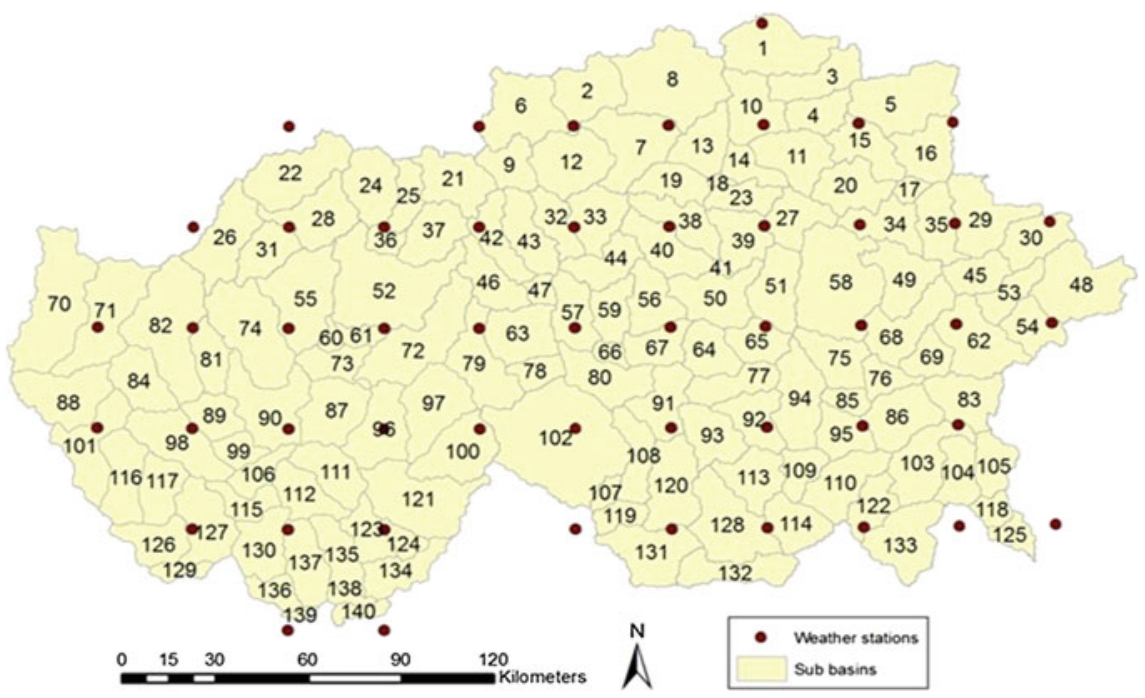

Fig. 12.7 Weather stations used in this project. Source Hydromet data (2013)

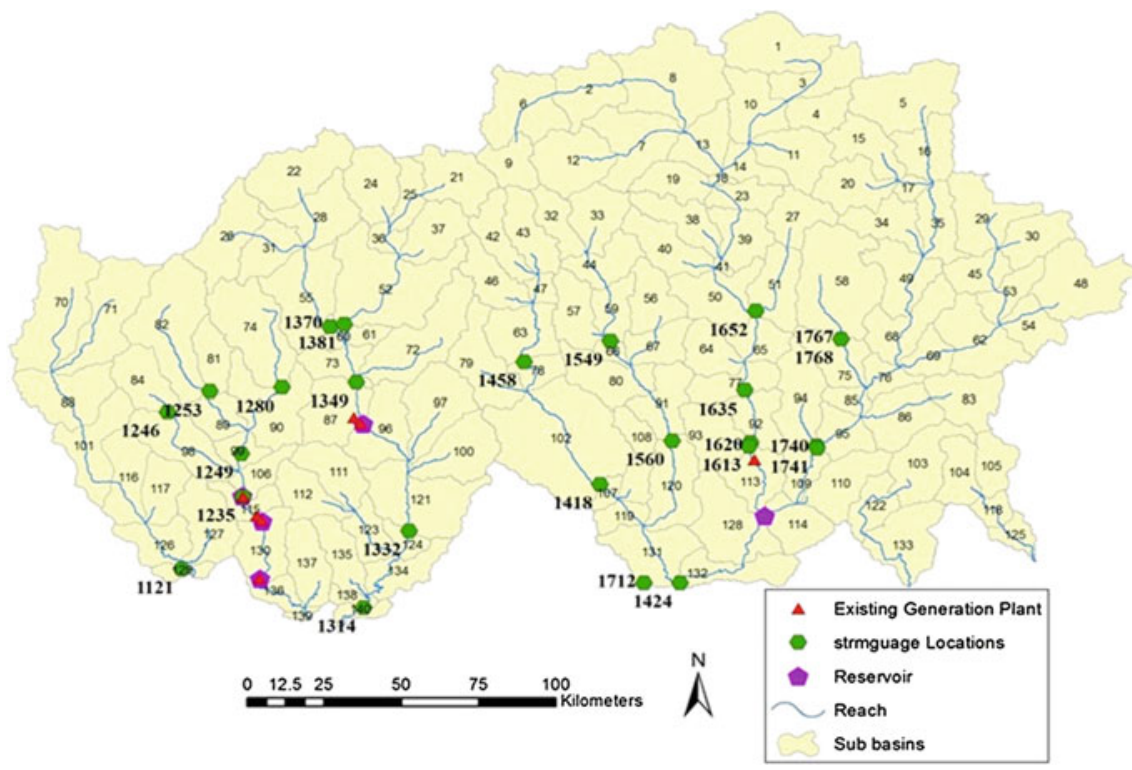

Fig. 12.8 Stream gauging stations available in the basin. Source Hydromet data (2013). Note: strmguage stream gauge 
Table 12.5 List of available gauging stations

\begin{tabular}{|c|c|c|c|c|c|c|}
\hline $\begin{array}{l}\text { Station } \\
\text { ID }\end{array}$ & Name & Sub-basin & $\begin{array}{l}\text { Elevation } \\
\text { (meters } \\
\text { above sea } \\
\text { level) }\end{array}$ & $\begin{array}{l}\text { Drainage } \\
\text { area } \\
\left(\mathrm{km}^{2}\right)\end{array}$ & Latitude & Longitude \\
\hline 1121 & $\begin{array}{l}\text { Doyagang on } \\
\text { Amochhu }\end{array}$ & 129 & 355 & 3650 & 26.89 & 89.34 \\
\hline 1235 & $\begin{array}{l}\text { Chimakoti Dam on } \\
\text { Wangchhu }\end{array}$ & 106 & 1820 & 3550 & 27.11 & 89.53 \\
\hline 1246 & Hachhu & 84 & 2700 & 320 & 27.37 & 89.29 \\
\hline 1249 & $\begin{array}{l}\text { Damchhu on } \\
\text { Wanchhu }\end{array}$ & 99 & 1990 & 2520 & 27.24 & 89.53 \\
\hline 1253 & Parochhu & 82 & 2255 & 1049 & 27.43 & 89.43 \\
\hline 1280 & $\begin{array}{l}\text { Lungtenphug on } \\
\text { Wangchhu }\end{array}$ & 74 & 2260 & 663 & 27.45 & 89.66 \\
\hline 1314 & $\begin{array}{l}\text { Kerabari on } \\
\text { Sankosh }\end{array}$ & 138 & 150 & 10,355 & 26.77 & 89.93 \\
\hline 1332 & Turitar on Sankosh & 121 & 320 & 8593 & 27.01 & 90.08 \\
\hline 1349 & $\begin{array}{l}\text { Wangdirapids on } \\
\text { Phochhu + Mochhu }\end{array}$ & 73 & 1190 & 6271 & 27.46 & 89.90 \\
\hline 1370 & Yebesa on Mochhu & 55 & 1230 & 2320 & 27.63 & 89.82 \\
\hline 1381 & $\begin{array}{l}\text { Samdingkha on Pho } \\
\text { chhu }\end{array}$ & 52 & 1220 & 1284 & 27.64 & 89.86 \\
\hline 1418 & $\begin{array}{l}\text { Tingtibi on } \\
\text { Mangdechhu Down } \\
\text { Stream } \\
\end{array}$ & 102 & 530 & 3322 & 27.15 & 90.70 \\
\hline 1424 & $\begin{array}{l}\text { Tingtibi on } \\
\text { Dakpichhu }\end{array}$ & 132 & 580 & 122 & 26.84 & 90.96 \\
\hline 1458 & $\begin{array}{l}\text { Bjizam on } \\
\text { Mangdechhu }\end{array}$ & 63 & 1848 & 1390 & 27.52 & 90.45 \\
\hline 1549 & $\begin{array}{l}\text { Kurjey on } \\
\text { Chamkharchhu }\end{array}$ & 59 & 2600 & 1350 & 27.59 & 90.74 \\
\hline 1560 & $\begin{array}{l}\text { Bemethang on } \\
\text { Chamkharchhu } \\
\text { (Singkhar) }\end{array}$ & 91 & 320 & - & 27.28 & 90.94 \\
\hline 1613 & $\begin{array}{l}\text { Lingmethang on } \\
\text { Maurichhu }\end{array}$ & 93 & 565 & 284 & 27.26 & 91.19 \\
\hline 1620 & $\begin{array}{l}\text { Kurizampa on } \\
\text { Kurichhu }\end{array}$ & 92 & 519 & 8600 & 27.27 & 91.19 \\
\hline 1635 & $\begin{array}{l}\text { Autsho on } \\
\text { Kurichhu }\end{array}$ & 77 & 814 & 8453 & 27.43 & 91.18 \\
\hline 1652 & Sumpa on Kurichhu & 50 & 1170 & - & 27.68 & 91.22 \\
\hline 1712 & $\begin{array}{l}\text { Panbang on } \\
\text { Dangmechhu }\end{array}$ & & 136 & 20,925 & 26.84 & 90.84 \\
\hline 1740 & Uzorong on Gongri & 95 & 554 & 8560 & 27.26 & 91.41 \\
\hline
\end{tabular}


Table 12.5 (continued)

\begin{tabular}{l|l|l|l|l|l|l}
\hline $\begin{array}{l}\text { Station } \\
\text { ID }\end{array}$ & Name & Sub-basin & $\begin{array}{l}\text { Elevation } \\
(\text { meters } \\
\text { above sea } \\
\text { level })\end{array}$ & $\begin{array}{l}\text { Drainage } \\
\text { area } \\
\left(\mathrm{km}^{2}\right)\end{array}$ & Latitude & Longitude \\
\hline 1741 & $\begin{array}{l}\text { Sherichhu on } \\
\text { Sherichhu }\end{array}$ & 94 & 542 & 437 & 27.25 & 91.41 \\
\hline 1767 & $\begin{array}{l}\text { Muktirap on } \\
\text { Kholong Chhu }\end{array}$ & 58 & 1640 & 905 & 27.59 & 91.49 \\
\hline
\end{tabular}

Source Hydromet data (2013)

Note Sub-basin numbers indicate the contributing sub-basins for each gauging station. Dashes indicate no data

\section{Project Setup}

Watershed delineation The basin was delineated using a DEM in SWAT. The maximum drainage area threshold was 22,500 ha. When a gauging station was available for calibration, an outlet was inserted manually, splitting the sub-basin in two, with a gauged upper half and non-gauged lower half.

Automatic sub-basin delineation, based on given threshold areas and manual input of sub-basin outlets, generated 140 sub-basins (Fig. 12.9). SWAT then divided each sub-basin into more detailed HRUs. HRUs represent unique combinations of land use, soil type, and slope. SWAT delineates HRUs with user-defined thresholds represented as percentages of each land use, soil type, and slope. In this project, land use and soil type thresholds were set at $2 \%$, meaning that any land use covering more than $2 \%$ of a sub-basin was considered an HRU, and from that

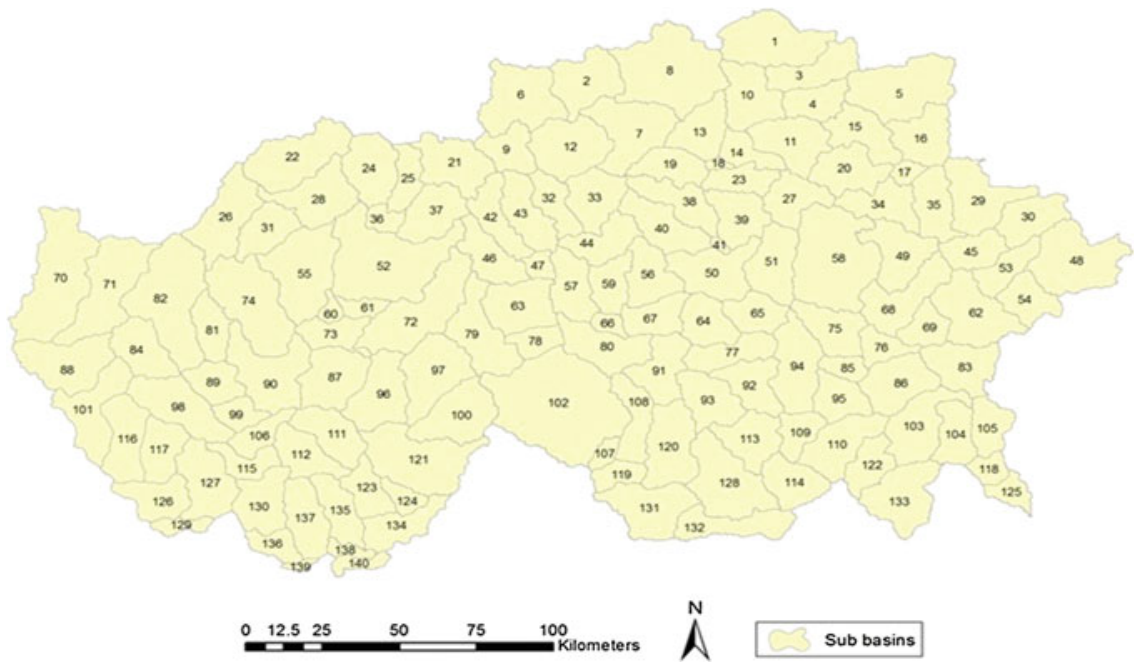

Fig. 12.9 Map of the basin showing sub-basin delineation. Source Hydromet data (2013) 
portion of land use, any soil type covering more than $2 \%$ was considered an HRU. These thresholds were chosen to avoid creating too many HRUs, which would make analyses too complicated and time consuming for the model process.

Based on the thresholds selected, there were a total of 4508 HRUs in the basin. These HRUs can be used for analyses on a particular land use or soil type.

HEP plant and reservoirs: All of the hydroelectric plants in this study generate power through run-of-the-river hydroelectricity. Five reservoirs were modeled at sub-basins 87, 106, 113, 115, and 130 (Fig. 12.8). The Tala Hydropower plant located at Wangchu contains a 92-m-high concrete dam and underground powerhouse. The Kurichhu Hydropower plant-located on Kurichhu river in the Mongar District - consists of a dam and has a 1-million-cubic-meter capacity cement reservoir and four turbines. The plant became operational on a staggered basis between April 2001 and May 2002. The list of the dams and HEP plants are summarized in Table 12.6.

Point sources: This study did not include any point sources, but they were set up in most modeled sub-basins for future use. All outputs from point sources were set to zero in this project. There is no wastewater treatment in Bhutan.

\section{Model Calibration and Validation}

Monthly streamflows were simulated against gauging station data; however, time periods with available data varied by gauging station (Table 12.7).

For statistical analyses of the calibration and validation, coefficient of determination $\left(R^{2}\right)$, Nash-Sutcliffe model efficiency (NSE; Nash and Sutcliffe 1970), and percent bias (PBIAS) were examined. $R^{2}$ can range from 0.0 to 1.0 , with higher values' indicating better model performance in predicting the variations of observed data. NSE indicates how well the plot of observed versus simulated data fits the 1:1 line. NSE ranges from $-\infty$ to $1.0 ; 1.0$ indicates a perfect fit, and negative values indicate that average values of observed data are more reliable than the model predictions. Positive values show a better match of observed data and predicted values. NSE is calculated with Eq. 12.1:

$$
\boldsymbol{N S E}=1-\frac{\sum_{i=1}^{n}\left(\boldsymbol{O}_{i}-\boldsymbol{P}_{i}\right)^{2}}{\sum_{i=1}^{n}\left(\boldsymbol{O}_{i}-\overline{\boldsymbol{O}}\right)^{2}}
$$

where $\mathrm{O}$ is the observed statistic for month $i$, $\mathrm{P}$ is the SWAT-simulated statistic for the same month $\mathrm{i}$, and = the average of all the monthly observation data.

PBIAS measures the average tendency of the simulated data to be larger or smaller than their observed counterparts (Gupta et al. 1999). The optimal value of PBIAS is 0.0 , with low values' indicating accurate model simulation in term of magnitude. Positive values indicate model underestimation bias, and negative values indicate model overestimation bias (Gupta, et al. 1999). It is calculated as 


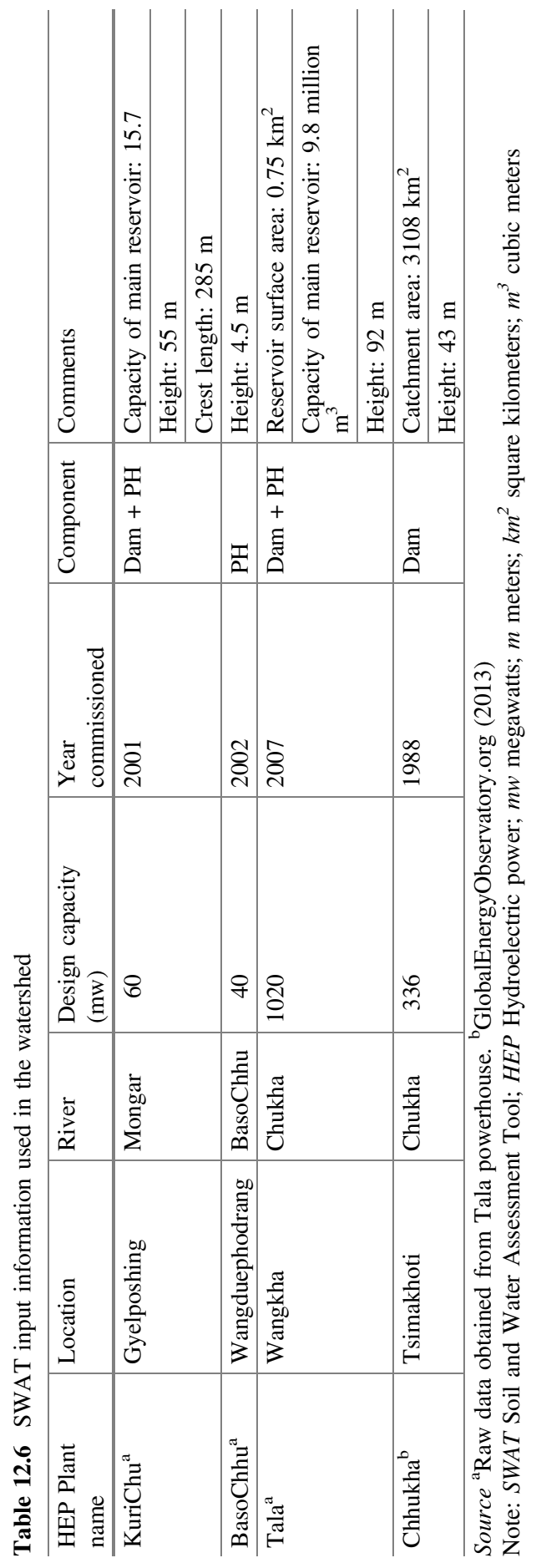


Table 12.7 Comparison statistics of simulated and actual monthly streamflow at 20 monitoring sites

\begin{tabular}{l|l|l|r|r|l|l|l|l|r}
\hline $\begin{array}{l}\text { Station } \\
\text { ID }\end{array}$ & $\begin{array}{l}\text { Sub-basin } \\
\text { number }\end{array}$ & $R^{2}$ & NSE & PBIAS & $\begin{array}{l}\text { Station } \\
\text { ID }\end{array}$ & $\begin{array}{l}\text { Sub-basin } \\
\text { number }\end{array}$ & $R^{2}$ & NSE & PBIAS \\
\hline 1121 & 129 & 0.87 & 0.74 & +1.80 & 1418 & 102 & 0.94 & 0.81 & +13.03 \\
\hline 1246 & 84 & 0.89 & 0.56 & -33.89 & 1424 & 132 & 0.93 & 0.84 & +4.04 \\
\hline 1249 & 99 & 0.90 & 0.79 & +9.10 & 1458 & 63 & 0.86 & 0.75 & +1.28 \\
\hline 1253 & 82 & 0.90 & 0.77 & -2.39 & 1549 & 59 & 0.94 & 0.87 & +1.81 \\
\hline 1280 & 74 & 0.92 & 0.83 & +13.00 & 1560 & 91 & 0.93 & 0.81 & +14.00 \\
\hline 1314 & 138 & 0.91 & 0.44 & +44.17 & 1620 & 92 & 0.80 & 0.15 & +28.84 \\
\hline 1332 & 121 & 0.89 & 0.37 & +49.67 & 1635 & 77 & 0.77 & -0.80 & -56.80 \\
\hline 1349 & 73 & 0.89 & -40.86 & +37.20 & 1652 & 50 & 0.70 & -1.61 & -61.66 \\
\hline 1370 & 55 & 0.85 & 0.46 & -1.61 & 1740 & 95 & 0.88 & 0.82 & +6.16 \\
\hline 1381 & 52 & 0.79 & -0.05 & +1.40 & 1767 & 58 & 0.83 & 0.19 & +45.75 \\
\hline
\end{tabular}

Source Hydromet raw data

Note: NSE Nash-Sutcliffe model efficiency; PBIAS percent bias

$$
\boldsymbol{P B I A S}=\left[\frac{\sum_{i=1}^{n}\left(\boldsymbol{O}_{i}-\boldsymbol{P}_{i}\right) * 100}{\sum_{i=1}^{n} \boldsymbol{O}_{i}}\right]
$$

$\mathrm{P}=\mathrm{SWAT}$ prediction. All other variables are as defined in Eq. 12.1.

According to Moriasi et al. (2007), model predictions can be classified as satisfactory if $0.5<\mathrm{NSE} \leq 0.65$ while $\pm 15 \% \leq$ PBIAS $< \pm 25 \%$, good if $0.65<$ NSE $\leq 0.75$ while $\pm 10 \% \leq$ PBIAS $< \pm 15 \%$, and very good if $0.75<$ NSE $\leq 1.00$ while PBIAS $\leq \pm 10 \%$. Model performance is unsatisfactory if NSE $\leq 0.5$ and PBIAS $\geq \pm 25 \%$.

Tables 12.7 and 12.8 include statistical comparisons of long-term means, standard deviations, $R^{2}$, NSE, and PBIAS. Model performance statistics used to assess calibration efforts indicate that SWAT model estimates are satisfactory with a range of $0.70-0.94$ for $R^{2}$ and an NSE value greater than 0.50 for 11 gauged subwatersheds and unsatisfactory with an NSE value less than 0.50 for 9 subwatersheds. Differences between observed and modeled monthly streamflow, averaged over the entire simulation period at each gauging station, range from 1.45 to $61.67 \%$ with an average difference of $+3.92 \%$ (Table 12.7). Table 12.9 presents predicted average monthly outflow from sub-basins for the relevant simulation period. Average monthly and annual basin values are presented in Table 12.10 and Table 12.11, respectively. According to the model outputs, $70 \%$ of fallen snow is melted or evaporated, and only $5 \%$ of total precipitation remains on the ground and is added to the snowpack each year.

Overall, the model compared well at a monthly temporal scale across 11 monitoring sites, given the input data developed in this study, while predicted flow from gauging stations on the Kurichhu $(1620,1635,1652)$ and Puntasangchhu (1381, $1349,1370)$ was not satisfactory. The main reason for poor results in these stations could be associated with the large gaps in precipitation data at these regions. 
Table 12.8 Multiyear average and standard deviation of monthly streamflow

\begin{tabular}{|c|c|c|c|c|c|c|}
\hline \multirow[t]{2}{*}{$\begin{array}{l}\text { Station } \\
\text { ID }\end{array}$} & \multirow[t]{2}{*}{$\begin{array}{l}\text { Sub-basin } \\
\text { number }\end{array}$} & \multicolumn{2}{|c|}{$\begin{array}{l}\text { Monthly average flow } \\
(\mathrm{cm})\end{array}$} & \multicolumn{2}{|c|}{ Standard deviation } & \multirow[t]{2}{*}{$\begin{array}{l}\text { Simulation } \\
\text { period }\end{array}$} \\
\hline & & Observed & Simulated & Observed & Simulated & \\
\hline 1121 & 129 & 182.39 & 179.74 & 169.45 & 125.00 & 2006-2012 \\
\hline 1246 & 84 & 5.75 & 7.70 & 4.44 & 4.81 & 2000-2012 \\
\hline 1249 & 99 & 65.84 & 59.85 & 60.34 & 57.27 & 2002-2012 \\
\hline 1253 & 82 & 25.51 & 25.96 & 25.17 & 26.52 & 1997-2012 \\
\hline 1280 & 74 & 22.77 & 19.81 & 22.02 & 21.47 & 1997-2012 \\
\hline 1314 & 138 & 454.01 & 256.35 & 409.39 & 217.69 & 2007-2012 \\
\hline 1332 & 121 & 359.47 & 180.90 & 315.62 & 147.77 & 2006-2012 \\
\hline 1349 & 73 & 296.69 & 186.32 & 256.57 & 158.73 & 2003-2012 \\
\hline 1370 & 55 & 113.49 & 111.44 & 105.50 & 90.34 & 2005-2012 \\
\hline 1381 & 52 & 43.06 & 42.45 & 31.61 & 41.40 & 2008-2012 \\
\hline 1418 & 102 & 147.76 & 128.50 & 121.49 & 89.04 & 2005-2012 \\
\hline 1424 & 132 & 723.80 & 694.53 & 695.11 & 552.31 & 2011-2012 \\
\hline 1458 & 63 & 59.78 & 58.25 & 52.02 & 51.86 & 2003-2012 \\
\hline 1549 & 59 & 53.64 & 52.31 & 46.87 & 47.23 & 1997-2012 \\
\hline 1560 & 91 & 97.06 & 83.46 & 82.72 & 63.54 & 2009-2012 \\
\hline 1620 & 92 & 272.16 & 332.13 & 222.86 & 320.57 & 2006-2012 \\
\hline 1635 & 77 & 223.39 & 329.42 & 178.59 & 318.37 & 2006-2012 \\
\hline 1652 & 50 & 176.39 & 285.16 & 149.86 & 291.83 & 2007-2012 \\
\hline 1740 & 95 & 304.89 & 286.11 & 236.06 & 205.83 & 1997-2012 \\
\hline 1767 & 58 & 64.96 & 35.14 & 53.57 & 20.76 & 2001-2012 \\
\hline
\end{tabular}

Source Soil and Water Assessment Tool results (2013)

Considerable uncertainty has been reported for the variations of precipitation with elevation in the mountainous terrain of Bhutan as well. For further improvements in monthly streamflow, more detailed information (for example, reservoirs, dams, and irrigation) needs to be collected.

To save space, six gauges - two in the west (1249 and 1121), one in the northwestern mountains (1370), two in the lower middle (1418 and 1549), and one in the east of the basin (1740)_-were used to graphically illustrate simulated and observed streamflow. The simulated and observed streamflow at these gauges is shown in Fig. 12.10. Flow time series curves show the model captured well seasonal variation in streamflow, snowmelt, and evapotranspiration, although peaks are not always perfectly simulated. The hydrological regime of the rivers in this region is characterized by low flow in the cold dry winter, resulting in accumulation of snow at high altitudes, and high flow during summer caused by monsoon precipitation and melting of glacier ice and snow.

Snow season in the mountain area elevation of $3000 \mathrm{~m}$ often starts from late autumn to the next early summer. In the pre-monsoon and early monsoon season (May to July), snowmelt from all subwatersheds contributes significantly to river 
Table 12.9 Average monthly streamflow from sub-basins

\begin{tabular}{|c|c|c|c|c|c|c|c|c|}
\hline $\begin{array}{l}\text { Reach } \\
\text { number }\end{array}$ & $\begin{array}{l}\text { Area } \\
\left(\mathrm{km}^{2}\right)\end{array}$ & $\begin{array}{l}\text { Flow } \\
(\mathrm{cm})\end{array}$ & $\begin{array}{l}\text { Sub-basin } \\
\text { number }\end{array}$ & $\begin{array}{l}\text { Area } \\
\left(\mathrm{km}^{2}\right)\end{array}$ & $\begin{array}{l}\text { Flow } \\
(\mathrm{cm})\end{array}$ & $\begin{array}{l}\text { Sub-basin } \\
\text { number }\end{array}$ & $\begin{array}{l}\text { Area } \\
\left(\mathrm{km}^{2}\right)\end{array}$ & $\begin{array}{l}\text { Flow } \\
(\mathrm{cm})\end{array}$ \\
\hline 1 & 546.30 & 4.22 & 48 & 594.90 & 21.90 & 95 & 8304.00 & 289.30 \\
\hline 2 & 1166.00 & 41.11 & 49 & 2686.00 & 92.39 & 96 & 6492.00 & 157.60 \\
\hline 3 & 865.60 & 8.86 & 50 & 7280.00 & 167.90 & 97 & 480.20 & 6.62 \\
\hline 4 & 234.20 & 2.09 & 51 & 659.00 & 14.11 & 98 & 778.60 & 14.50 \\
\hline 5 & 619.80 & 20.14 & 52 & 2342.00 & 42.54 & 99 & 2605.00 & 59.96 \\
\hline 6 & 766.90 & 11.51 & 53 & 1213.00 & 46.46 & 100 & 441.20 & 15.35 \\
\hline 7 & 983.80 & 30.17 & 54 & 843.90 & 33.39 & 101 & 2352.00 & 102.10 \\
\hline 8 & 2017.00 & 52.45 & 55 & 2301.00 & 87.43 & 102 & 3319.00 & 149.10 \\
\hline 9 & 243.30 & 1.34 & 56 & 310.10 & 13.15 & 103 & 418.10 & 10.18 \\
\hline 10 & 1474.00 & 17.42 & 57 & 306.20 & 9.11 & 104 & 260.00 & 5.79 \\
\hline 11 & 387.00 & 5.13 & 58 & 882.50 & 37.59 & 105 & 225.60 & 5.14 \\
\hline 12 & 469.60 & 23.05 & 59 & 1378.00 & 52.94 & 106 & 3558.00 & 76.67 \\
\hline 13 & 3311.00 & 91.41 & 60 & 2361.00 & 87.81 & 107 & 3393.00 & 150.80 \\
\hline 14 & 2043.00 & 26.51 & 61 & 2438.00 & 43.39 & 108 & 281.70 & 9.72 \\
\hline 15 & 321.00 & 5.67 & 62 & 2556.00 & 99.87 & 109 & 8942.00 & 310.20 \\
\hline 16 & 957.30 & 29.86 & 63 & 1388.00 & 76.59 & 110 & 386.30 & 7.10 \\
\hline 17 & 737.50 & 16.24 & 64 & 274.70 & 8.26 & 111 & 321.50 & 3.44 \\
\hline 18 & 5384.00 & 118.70 & 65 & 8175.00 & 185.60 & 112 & 283.40 & 1.64 \\
\hline 19 & 258.80 & 5.82 & 66 & 1451.00 & 53.54 & 113 & 9664.00 & 205.80 \\
\hline 20 & 343.50 & 7.17 & 67 & 557.00 & 15.77 & 114 & 9624.00 & 348.40 \\
\hline 21 & 397.50 & 3.47 & 68 & 3094.00 & 108.10 & 115 & 3739.00 & 98.68 \\
\hline 22 & 537.70 & 21.78 & 69 & 2747.00 & 103.90 & 116 & 2724.00 & 105.90 \\
\hline 23 & 5850.00 & 129.30 & 70 & 816.80 & 42.12 & 117 & 276.50 & 3.22 \\
\hline 24 & 374.20 & 4.10 & 71 & 612.50 & 31.52 & 118 & 600.60 & 13.08 \\
\hline 25 & 594.00 & 8.06 & 72 & 638.30 & 15.29 & 119 & 3817.00 & 163.80 \\
\hline 26 & 461.00 & 23.16 & 73 & 5662.00 & 148.20 & 120 & 3177.00 & 88.56 \\
\hline 27 & 287.60 & 5.58 & 74 & 663.40 & 19.94 & 121 & 8064.00 & 186.00 \\
\hline 28 & 953.00 & 39.25 & 75 & 1196.00 & 45.51 & 122 & 650.00 & 14.24 \\
\hline 29 & 452.20 & 18.55 & 76 & 6003.00 & 215.30 & 123 & 831.10 & 6.43 \\
\hline 30 & 303.70 & 7.97 & 77 & \begin{tabular}{|l|l|}
8722.00 \\
\end{tabular} & 196.70 & 124 & 8175.00 & 186.50 \\
\hline 31 & 738.20 & 35.00 & 78 & 1541.00 & 80.34 & 125 & 727.80 & 26.47 \\
\hline 32 & 226.50 & 9.40 & 79 & 454.50 & 18.75 & 126 & 3280.00 & 141.60 \\
\hline 33 & 330.10 & 14.80 & 80 & 2390.00 & 73.26 & 127 & 412.10 & 48.67 \\
\hline 34 & 304.90 & 14.28 & 81 & 232.50 & 5.12 & 128 & $19,850.00$ & 559.10 \\
\hline 35 & 2000.00 & 60.71 & 82 & 808.40 & 26.11 & 129 & 3785.00 & 200.90 \\
\hline 36 & 1070.00 & 17.22 & 83 & 359.50 & 11.39 & 130 & 4078.00 & 141.30 \\
\hline 37 & 338.90 & 5.02 & 84 & 323.50 & 7.69 & 131 & 7445.00 & 262.50 \\
\hline 38 & 312.00 & 8.08 & 85 & 7313.00 & 265.20 & 132 & $20,170.00$ & 593.10 \\
\hline 39 & 6160.00 & 136.00 & 86 & 743.10 & 19.74 & 133 & 1103.00 & 62.98 \\
\hline
\end{tabular}


Table 12.9 (continued)

\begin{tabular}{l|l|r|l|r|l|l|r|r}
\hline $\begin{array}{l}\text { Reach } \\
\text { number }\end{array}$ & $\begin{array}{l}\text { Area } \\
\left(\mathrm{km}^{2}\right)\end{array}$ & $\begin{array}{l}\text { Flow } \\
(\mathrm{cm})\end{array}$ & $\begin{array}{l}\text { Sub-basin } \\
\text { number }\end{array}$ & $\begin{array}{l}\text { Area } \\
\left(\mathrm{km}^{2}\right)\end{array}$ & $\begin{array}{l}\text { Flow } \\
(\mathrm{cm})\end{array}$ & $\begin{array}{l}\text { Sub-basin } \\
\text { number }\end{array}$ & $\begin{array}{l}\text { Area } \\
\left(\mathrm{km}^{2}\right)\end{array}$ & $\begin{array}{l}\text { Flow } \\
(\mathrm{cm})\end{array}$ \\
\hline 40 & 353.20 & 9.56 & 87 & 6072.00 & 153.00 & 134 & 9289.00 & 223.20 \\
\hline 41 & 6497.00 & 144.50 & 88 & 1914.00 & 91.20 & 135 & 270.10 & 29.25 \\
\hline 42 & 281.00 & 15.50 & 89 & 1266.00 & 32.36 & 136 & 4227.00 & 160.90 \\
\hline 43 & 328.20 & 19.13 & 90 & 1191.00 & 26.85 & 137 & 332.40 & 38.98 \\
\hline 44 & 838.70 & 38.41 & 91 & 2721.00 & 76.84 & 138 & 9627.00 & 260.10 \\
\hline 45 & 993.20 & 38.39 & 92 & 9017.00 & 199.20 & 139 & 4590.00 & 203.30 \\
\hline 46 & 301.30 & 22.53 & 93 & 323.40 & 4.07 & 140 & 9718.00 & 270.50 \\
\hline 47 & 694.90 & 39.00 & 94 & 448.40 & 19.55 & & & \\
\hline
\end{tabular}

Source Soil and Water Assessment Tool results (2013)

Note: $\mathrm{km}^{2}$ square kilometers; $\mathrm{cm}$ centimeters

Table 12.10 Average monthly basin values (millimeters)

\begin{tabular}{l|l|l|l|l|l|l}
\hline Month & Rain & $\begin{array}{l}\text { Snow } \\
\text { fall }\end{array}$ & $\begin{array}{l}\text { Surface } \\
\text { runoff }\end{array}$ & $\begin{array}{l}\text { Lateral } \\
\text { flow }\end{array}$ & $\begin{array}{l}\text { Water } \\
\text { yield }\end{array}$ & Evapotranspiration \\
\hline 1 & 18.61 & 11.95 & 0.37 & 0.69 & 25.60 & 15.25 \\
\hline 2 & 34.97 & 19.53 & 1.10 & 1.71 & 22.23 & 23.17 \\
\hline 3 & 63.76 & 27.75 & 4.09 & 4.65 & 25.72 & 34.46 \\
\hline 4 & 119.23 & 34.62 & 15.15 & 14.92 & 43.59 & 40.32 \\
\hline 5 & 155.05 & 28.12 & 35.78 & 25.86 & 75.14 & 45.94 \\
\hline 6 & 252.00 & 25.29 & 80.70 & 47.86 & 144.27 & 36.97 \\
\hline 7 & 308.85 & 31.15 & 97.25 & 67.94 & 188.66 & 29.74 \\
\hline 8 & 269.82 & 32.49 & 79.12 & 60.51 & 171.30 & 29.26 \\
\hline 9 & 188.69 & 26.95 & 49.55 & 43.57 & 129.29 & 30.24 \\
\hline 10 & 95.04 & 23.11 & 21.55 & 17.80 & 77.46 & 32.20 \\
\hline 11 & 17.45 & 9.77 & 0.91 & 1.97 & 36.04 & 23.47 \\
\hline
\end{tabular}

Source Soil and water assessment tool results (2013)

Table 12.11 Average annual basin values (millimeters)

\begin{tabular}{l|c|l|c}
\hline Precipitation & 1534.80 & Groundwater & 56.74 \\
\hline Snow fall & 277.70 & Deep aquifer discharge & 7.06 \\
\hline Snow melt & 173.54 & Total aquifer discharge & 353.20 \\
\hline Sublimation & 22.26 & Total water yield & 969.03 \\
\hline Surface runoff & 385.85 & Percolation out of soil & 353.19 \\
\hline Lateral soil flow & 288.14 & Evapotranspiration & 357.20 \\
\hline Shallow aquifer percolation & 295.05 & Potential evapotranspiration & 781.20 \\
\hline
\end{tabular}

Source Soil and water assessment tool results (2013) 

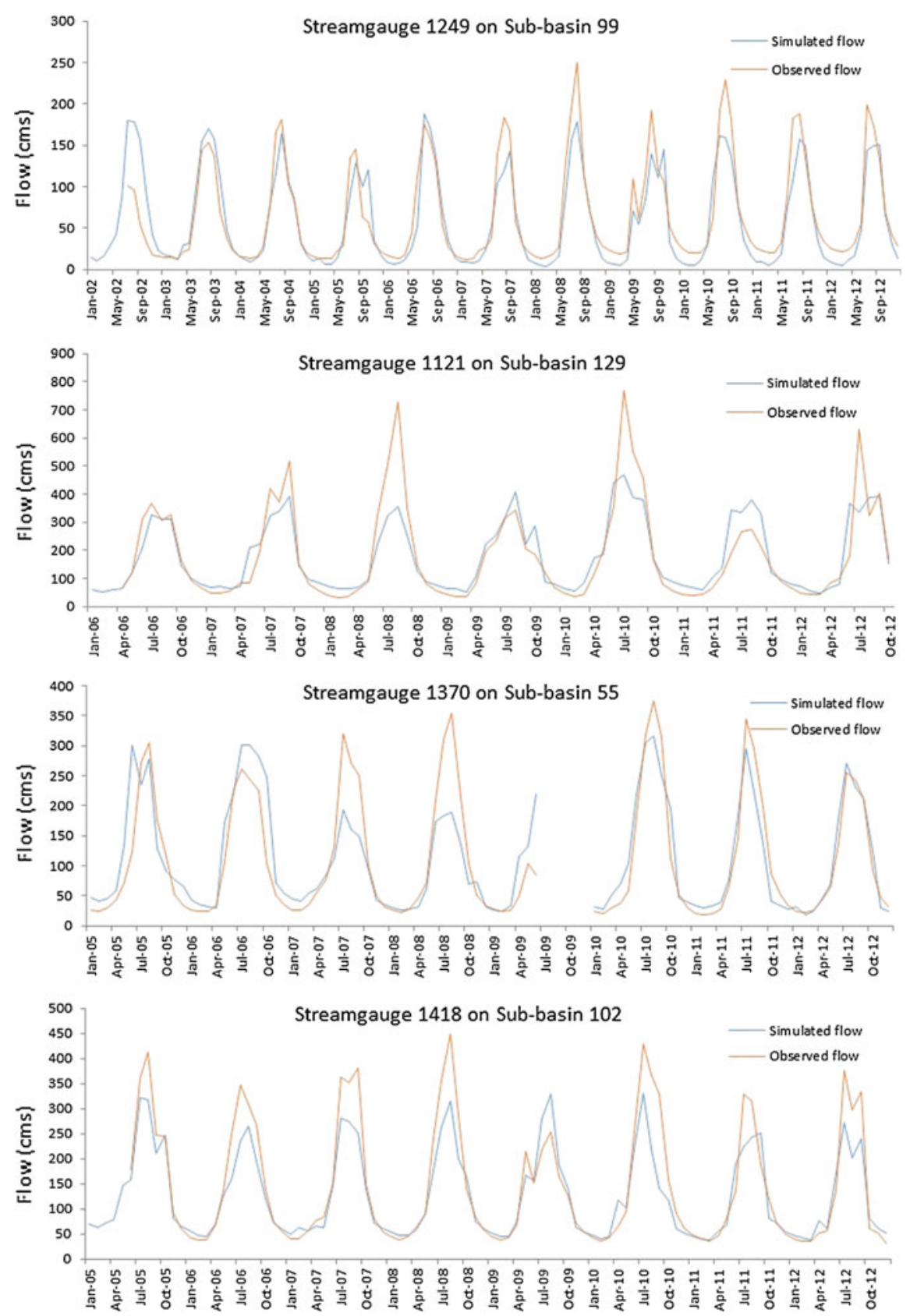

Fig. 12.10 Observed and simulated monthly streamflow $\left(\mathrm{m}^{3} / \mathrm{sec}\right)$ at selected gauges. Source Authors. Note: cms centimeters; Jan January; Sep September; Apr April; Jul July; Oct October. Gauges 1249 and 1121 in the west; 1370 in the northwestern mountains; 1418 and 1549 in the lower middle, and 1740 in the east of the basin 
12 Economics of Land Degradation and Improvement in Bhutan
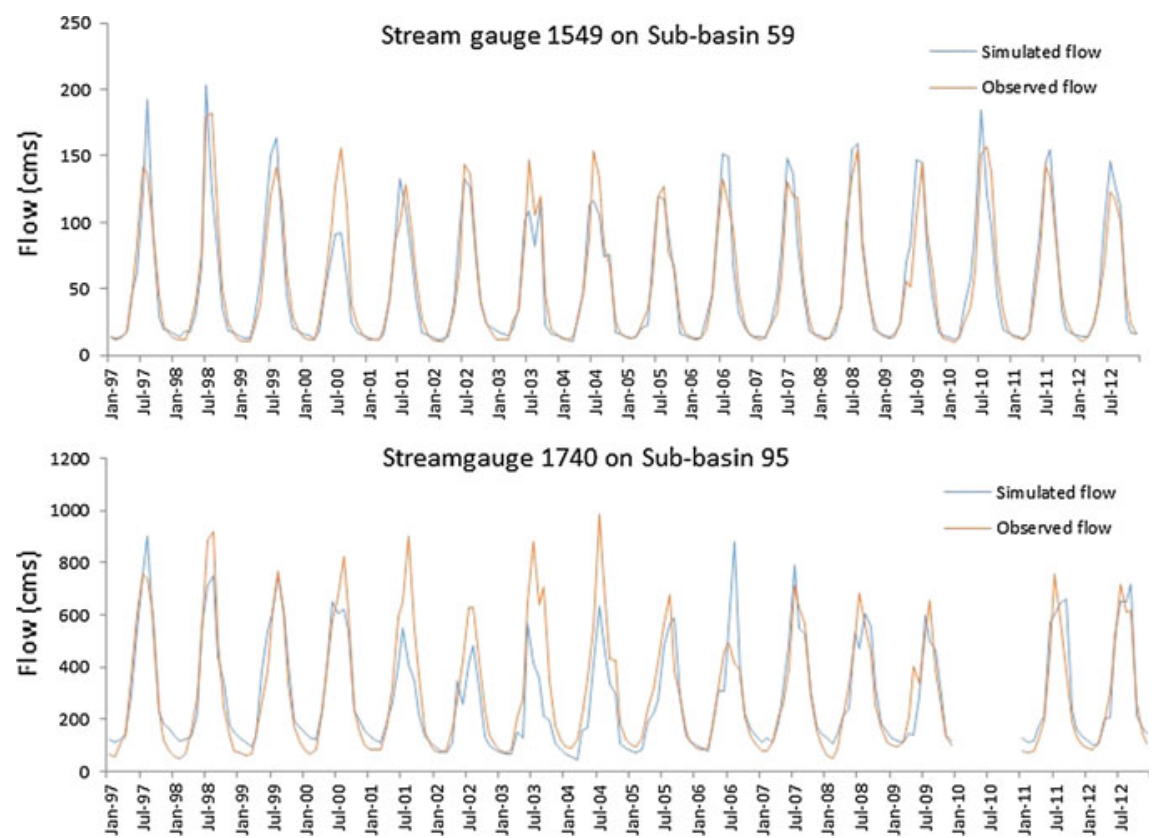

Fig. 12.10 (continued)

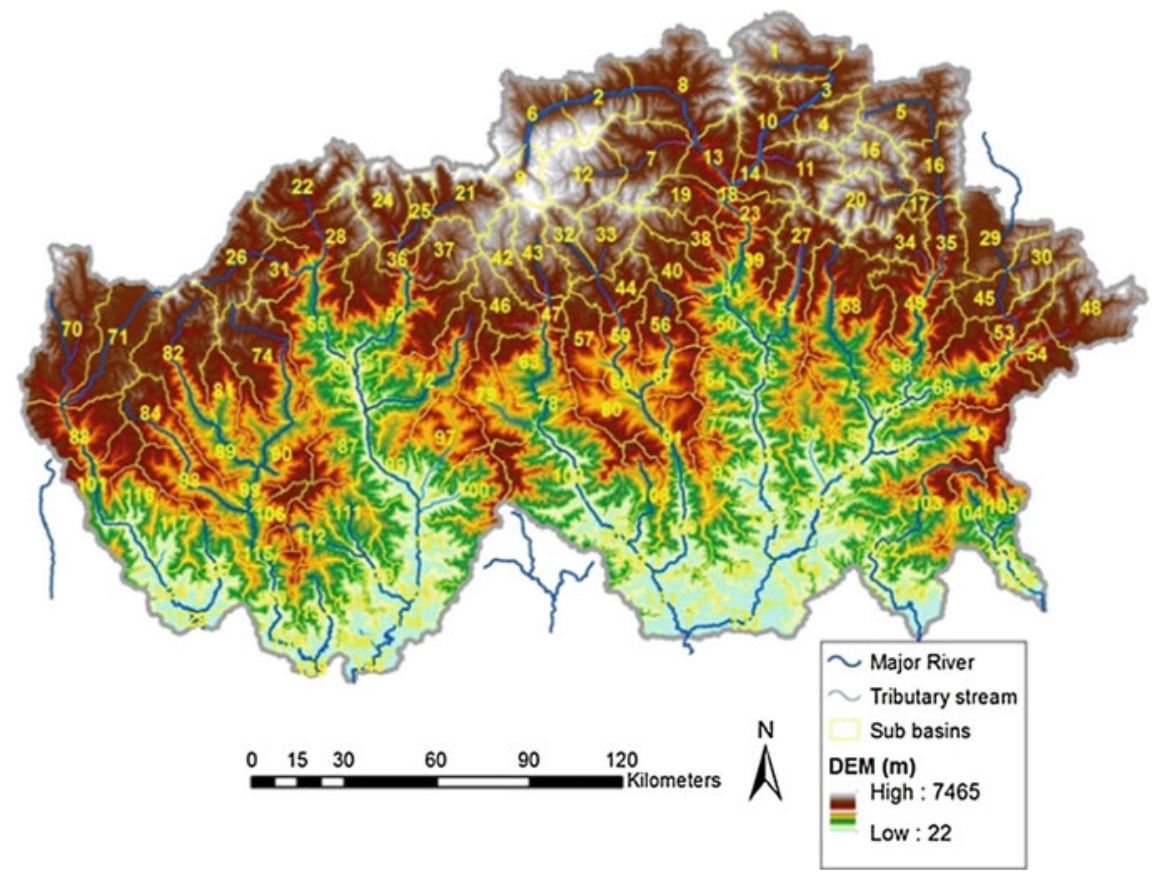

Fig. 12.11 Topographic situation of subwatersheds and gauging stations. Source National Soil Services Center data (2013). Note: DEM digital elevation model; $m$ meters 

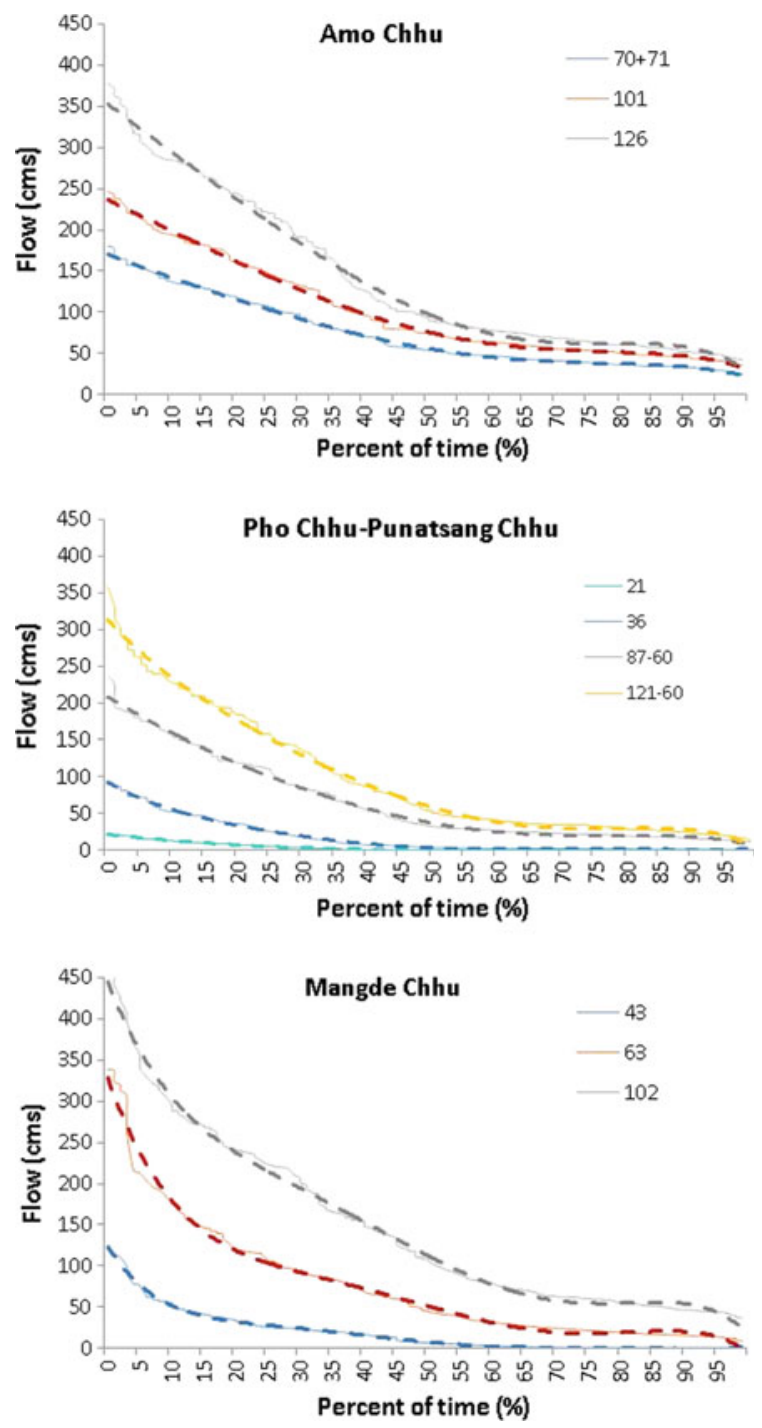

Fig. 12.11 (continued)

discharges. Every June to September is wet season, with frequent showers and night rainfalls. There is permanent snow cover in the area of elevation of 6000 meters. Sub-basins delineated by elevation is depicted in Fig. 12.11. 

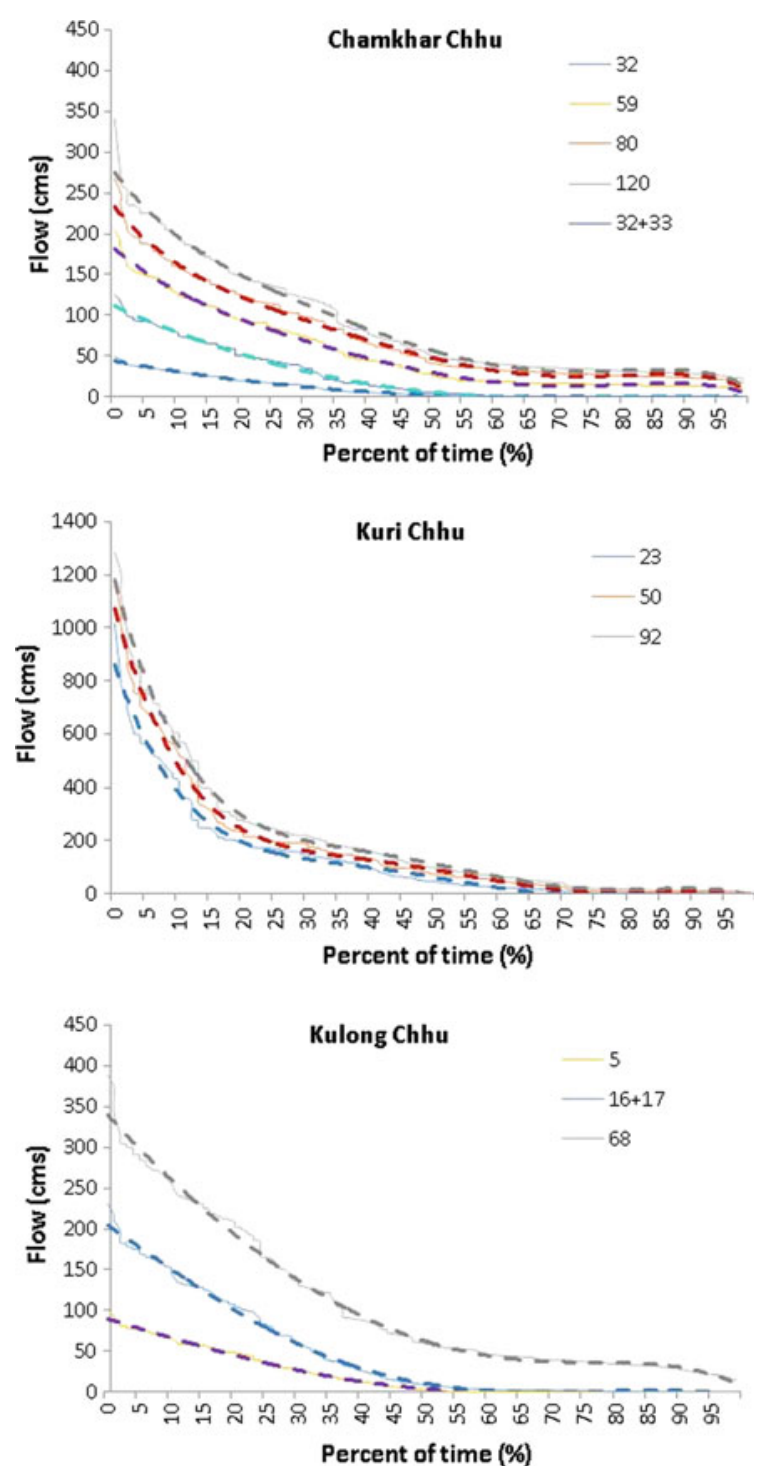

Fig. 12.11 (continued)

\section{Spatial Distribution of Hydrologic Components by Subwatersheds}

In southern subwatersheds with the elevation of $1500 \mathrm{~m}$, there are frequent heavy rains during summer and stream contribution dominated by rainfall (Fig. 12.13). Snowmelt from higher-elevation ranges contributes more water to discharge despite lower rainfall in these subwatersheds. Figure 12.14 shows the spatial distribution of 


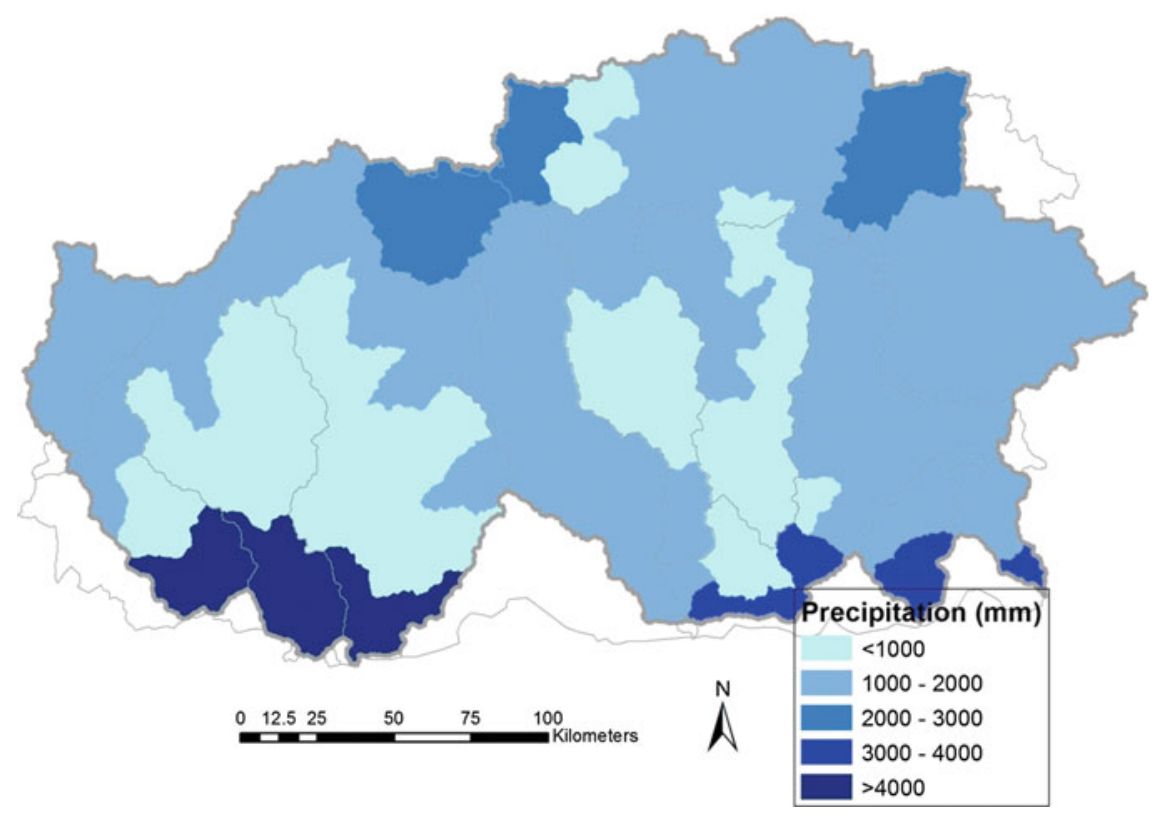

Fig. 12.12 Spatial distribution of average annual precipitation. Source Hydromet data (2013). Note: $\mathrm{mm}$ millimeters

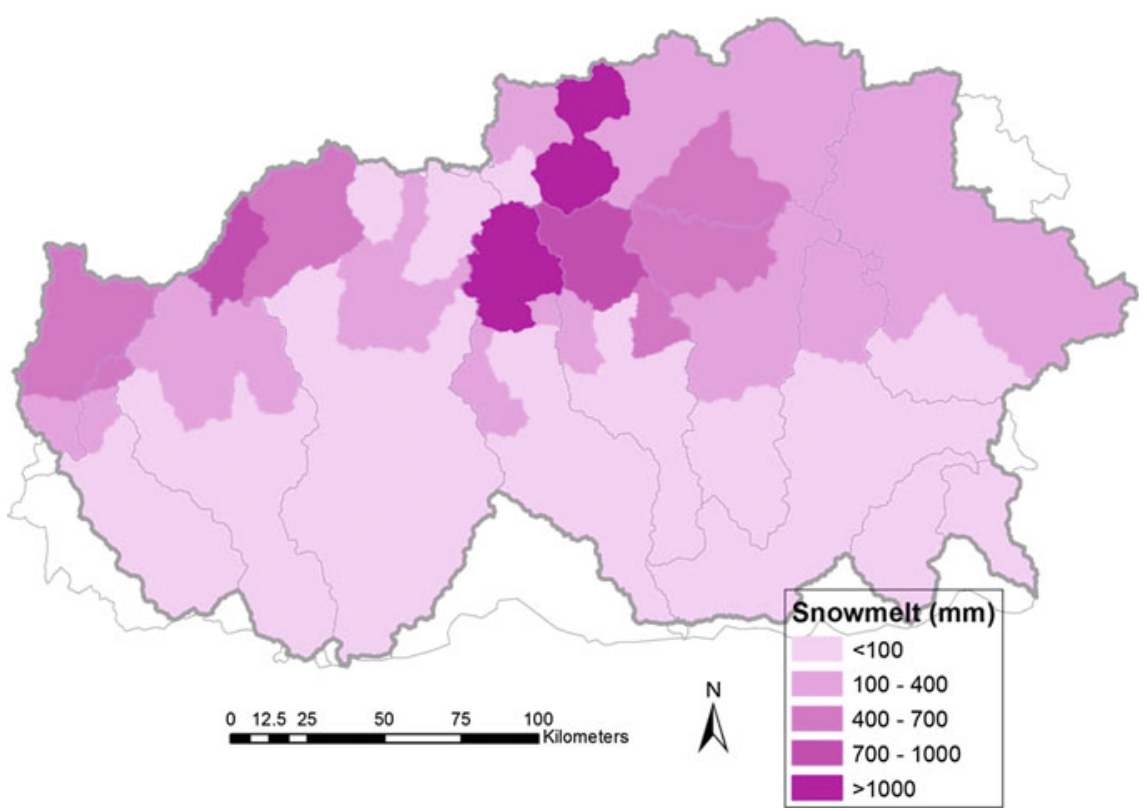

Fig. 12.13 Spatial distribution of average annual snowmelt. Source Hydromet data (2013). Note: $\mathrm{mm}$ millimeters 


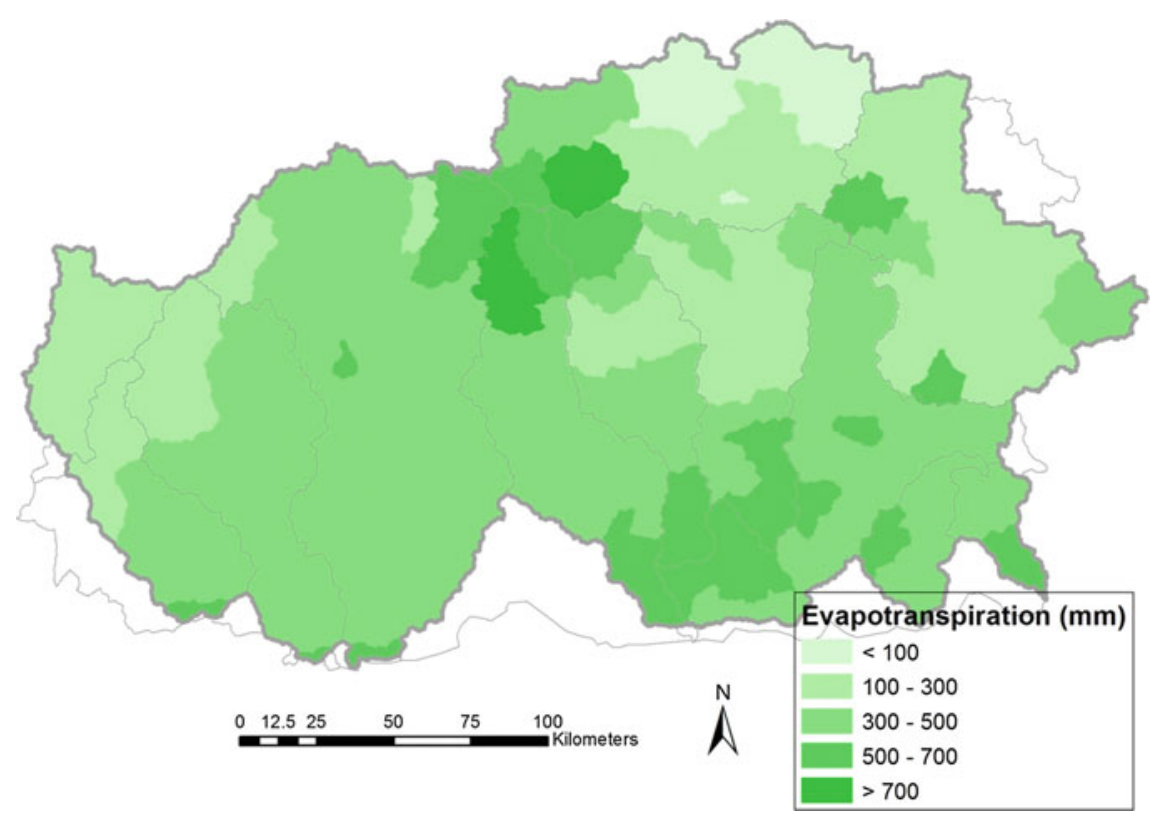

Fig. 12.14 Spatial distribution of average annual evapotranspiration. Source Hydromet data (2013). Note: $\mathrm{mm}$ millimeters

annual snowmelt. Note the high percentages derived from snowmelt in the upper central subwatersheds as well as in the high elevations (subwatersheds 42, 43, 48, 2, and 12). The frontal areas are dominated by rainfall and thus have a low snowmelt contribution. Figure 12.14 shows the evapotranspiration by sub-basin. Figure 12.15 shows the spatial distribution of surface runoff, which is highly dominated by rainfall contribution at the south and snowmelt contribution at mountainous subwatersheds (Fig. 12.12).

\section{Economic Analysis of SLM}

To assess the economic benefits of SLM, we estimate the benefits and costs of SLM practices and compare them with practices that are most prevalent in Bhutan-that is, business as usual (BAU). Since land degradation, SLM investments, and their returns are long-term processes, time series data are required to determine the impact of SLM on land productivity. For example, greater yield due to terraces built in one year to prevent soil erosion may prevail over many years. Similarly, plants established to fix nitrogen may take years to show significant impact on crop yield, but once well established, nitrogen fixation and consequent higher crop yield could continue until when the leguminous tree is cut. As mentioned earlier, our analysis will include both on-farm and off-farm costs of land degradation and benefits of 


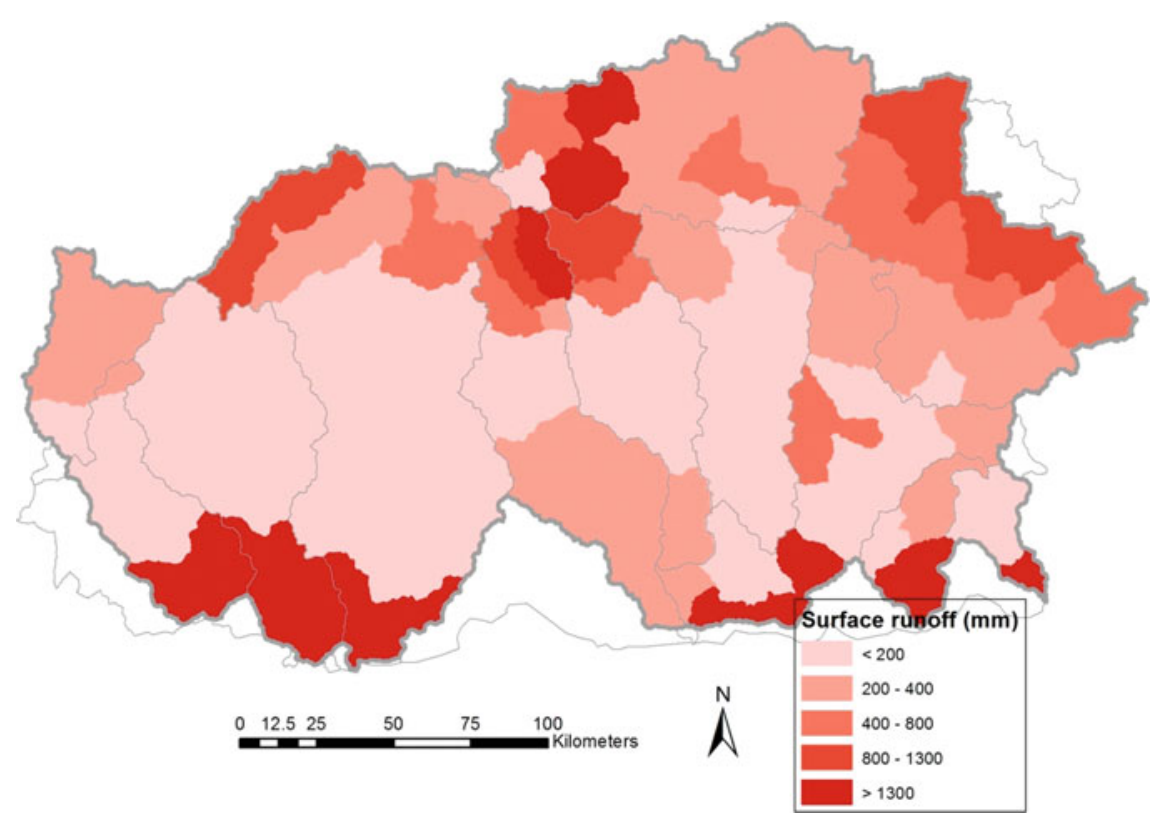

Fig. 12.15 Spatial distribution of average annual surface runoff. Source Hydromet data (2013). Note: $\mathrm{mm}$ millimeters

SLM. Assessment of the off-farm costs and benefits is complicated and difficult to measure (Berry et al. 2003; Hein 2006). Hence there has been a limited number of studies that have assessed the on-farm and off-site costs and benefits of land degradation and SLM investment. As mentioned earlier, the off-site benefits of SLM considered in this study are reductions in sediment loading. Accordingly, the off-site costs of land degradation are higher sediment loadings due to use of land-degrading practices. This study will use fairly simple methods and approaches that can be easily replicated in other studies. The approach compares profit of land productivity with and without SLM practices and includes both on-farm and off-site benefits and costs of management practices.

The returns to SLM investment (profit) analysis will be on a per-hectare basis for each of the major AEZs. However, for livestock production, the unit of analysis will be at the household level - the livestock production per household using SLM practices (that is, improved pasture management). To obtain national-level results, the results under each AEZ will be extrapolated to the relevant AEZ (Table 12.12).

\section{Factors Influencing Adoption of SLM Practices}

We analyze the drivers of adoption of SLM practices using the RNR 2009 data. Such analysis will help to determine the policies and strategies that could be used to achieve Bhutan's objectives of SLM stated in its 2020 Vision and other policies. 
Table 12.12 Agroecological zones and the corresponding agricultural enterprises

\begin{tabular}{|c|c|c|c|}
\hline $\begin{array}{l}\text { Agroecological } \\
\text { zone }\end{array}$ & \begin{tabular}{|l} 
Altitude \\
(meters above \\
sea level)
\end{tabular} & $\begin{array}{l}\text { Annual } \\
\text { rainfall } \\
(\mathrm{mm})\end{array}$ & Major enterprises \\
\hline Alpine & $3600-4600$ & $<650$ & $\begin{array}{l}\text { Yak herding by nomadic communities, dairy } \\
\text { products, barley, buckwheat, mustard, and } \\
\text { vegetables }\end{array}$ \\
\hline Cool temperate & $2600-3600$ & $650-850$ & $\begin{array}{l}\text { Yak, cattle, sheep, horses, dairy products, } \\
\text { barley, wheatand potatoes on dryland, } \\
\text { buckwheat and mustard under shifting } \\
\text { cultivation }\end{array}$ \\
\hline $\begin{array}{l}\text { Warm } \\
\text { temperate }\end{array}$ & $1800-2600$ & $650-850$ & $\begin{array}{l}\text { Rice on irrigated land, double cropped with } \\
\text { wheat and mustard; barley and potatoes on } \\
\text { dryland; temperate fruit trees; vegetables; } \\
\text { cattle }\end{array}$ \\
\hline Dry subtropical & 1200-1800 & $\begin{array}{l}850- \\
1200\end{array}$ & $\begin{array}{l}\text { Maize, rice, millet, pulses, fruit trees and } \\
\text { vegetables, wild lemon grass, cattle, pigs and } \\
\text { poultry }\end{array}$ \\
\hline $\begin{array}{l}\text { Humid } \\
\text { subtropical }\end{array}$ & $600-1200$ & $\begin{array}{l}1200- \\
2500\end{array}$ & $\begin{array}{l}\text { Irrigated rice rotated with mustard, wheat, } \\
\text { pulses, and vegetables; tropical fruit trees }\end{array}$ \\
\hline Wet subtropical & $150-600$ & $\begin{array}{l}2500- \\
5500\end{array}$ & $\begin{array}{l}\text { Irrigated rice rotated with mustard, wheat, } \\
\text { pulses, and vegetables; tropical fruit trees }\end{array}$ \\
\hline
\end{tabular}

Source Tobgay (2005)

Note: $\mathrm{mm}$ millimeters

Understanding of the factors influencing adoption of SLM practices will help the government to design strategies that will enhance adoption of SLM practices. The focus of the discussion will be on factors that have policy relevancy. These include farmer access to rural services (extension services and rural roads), land tenure security, and household physical capital endowment (land area and livestock) and human capital (sex and age of household head) (Barrett et al. 2002).

We use a nonlinear bivariate Probit model as specified below:

$$
\mathrm{P}\left(\mathbf{y}=1 \mid \mathbf{x}_{\mathbf{i}}\right)=f\left(\beta_{0}+\beta_{i} x_{i}+e_{i}\right),
$$

where $f(z)$ is normally distributed with a probability density function of the following:

$$
\frac{1}{\sigma \sqrt{2 \pi}} \exp \left(\frac{\left(x_{i}-\mu\right)^{2}}{2 \sigma^{2}}\right)
$$

where $\mathrm{P}=$ probability that the household uses SLM practices. $\mathrm{P}=1$ if the household uses SLM; $\mathrm{P}=0$ otherwise.

$$
\mathbf{x}_{\mathbf{i}}=\mathbf{x}_{1}+\mathbf{x}_{\mathbf{2}}+\mathbf{x}_{3}
$$


where $\mathbf{x}_{\mathbf{1}}=$ the vector of the household capital endowment - which includes human capital (age and sex household head); $\mathbf{x}_{2}=$ vector of land rights, method of acquisition (own land, renting, leasehold, and unused land-fallow), or both; $\mathbf{x}_{\mathbf{3}}=$ ownership of physical capital (livestock used as an indicator of physical capital); and $\mathbf{z}=$ vector of access to rural services (time to nearest road and access to extension services) and

$\beta_{\mathrm{i}}=$ coefficients associated with the corresponding covariate $i$.

The choice of covariates to include in the model was dictated by data availability. Some important variables - such as the level of education of the household head or other family members and total farm area-were not collected.

We do not include prices of commodities in this model since this is a generalized model that explains the adoption of any type of SLM practice-regardless of the type of land use (cropland, livestock, or forests). The next section on benefits-costs analysis of SLM will address price aspects.

Multicollinearity was not a serious problem since the average variance inflation factor was 2.28 and the largest variance inflation factor only 6.41 , less than 10 - a level deemed the threshold for serious bias due to multicollinearity (Mukherjee et al. 1998). We corrected for heteroskedasticity by estimating robust standard errors.

\section{Returns to SLM Practices}

\section{Profit with SLM Practices}

The general model for returns to SLM practices for all land use types (forest, cropland, and livestock) is given in Eq. 12.1, and the corresponding model for land-degrading practices is given in Eq. 12.2

$$
\pi_{t}^{c}=p_{t} y_{t}^{c}-z_{t}^{c}-\lambda_{t}
$$

where $\pi_{t}^{c}=$ profit per hectare or household with SLM practices in year $t$. For brevity, we will simply refer to returns per hectare, but this also means returns per household for livestock production land management practices

$y_{t}^{c} \quad$ Production per hectare with SLM practices in year $t$,

$\mathrm{P}_{\mathrm{t}}$ a constant price of output in year $\mathrm{t}$.

This will be the social price, that is, price that excludes market failures or policy-induced distortions - including subsidies and taxes.

$z_{t}^{c} \quad$ social cost of production using SLM practices per hectare in year $t$

$\lambda_{t}$ external (off-site) costs or benefit of SLM practice per hectare-for example, clearing forest area for crop production could lead to greater sediment loading in HEP dams. If $>0$, then off-site impact is a benefit to society, and if $\lambda t<0$, then off-site effect is a cost. 


\section{Profit with Land-degrading Practices (BAU)}

$$
\pi_{t}^{d}=p_{t} y_{t}^{d}-z_{t}^{d}-\tau_{t}
$$

where

$y_{t}^{d}$ production per hectare with BAU in year $t$,

$\pi_{t}^{d}$ profit with BAU per hectare in year $t$

$\mathrm{P}_{\mathrm{t}} \quad$ social price of one unit of output in year $\mathrm{t}$. A specific price will be applied for each enterprise analyzed (maize, rice, forest livestock products, and so forth). A private price is important to analyze since it determines farmers' choices to use SLM practices. However, we did not use it in this study since we used market prices that are not affected by government failure, subsidies, or taxes

$z_{t}^{d} \quad$ social cost of production of per hectare using land-degrading practices

$\tau_{t} \quad$ external (off-site) costs or benefit of land-degrading management practice per hectare, for example, sedimentation.

The decision by a landowner to use SLM will depend on the marginal rate of returns (MRR), which is defined as the returns per unit of investment. Holding all else constant, the higher the MRR, the greater is the uptake of SLM. For example, Heisey and Mwangi (1998) observed adoption of fertilizer among smallholder farmers in Africa south of the Sahara requires an MRR of at least $100 \%$; that is, for every unit of currency (for example, Bhutanese ngultrum) invested, one or more additional units are obtained.

MRR analysis will help to determine the attractiveness of SLM practices over time. MRR is given by

$$
M R R_{t}=\frac{\pi_{t}^{c}-\pi_{t}^{d}}{z_{t}^{c}+\lambda_{t}^{c}-z_{t}^{d}-\lambda_{t}^{d}}
$$

However, $\mathrm{MRR}_{\mathrm{t}}$ is given at one point in time, that is, $\mathrm{MRR}_{\mathrm{t}}$ in year $\mathrm{t}$. This could differ for each planning horizon. An analysis that looks at the streams of benefits of SLM and associated costs is the net present value (NPV). NPV is summed over the planning horizon and therefore reflects the benefits and costs of investment during the entire planning horizon (Gardner and Barrows 1985). The social NPV (NPV ${ }^{\mathrm{s}}$ ) of adopting SLM practices is therefore given by

$$
N P V=\rho^{t}\left\{\sum_{t=1}^{T}\left(\pi_{t}^{c}-\pi_{t}^{d}\right)\right\}
$$

where

$\mathrm{T}$ farmer's planning horizon

$\rho^{t}$ farmers' discount factor, where $r$ is the farmer's discount rate 
Discounting the future value is an integral part of farmers' decisionmaking processes (Duquette et al. 2011) as it reveals farmers' time preferences and risk attitudes. The discount rate varies widely even among poor farmers. Recent social experiments have elicited valuable information about farmer discount rates (Duflo et al. 2004; Duquette et al. 2011; D'Exelle et al. 2012). Using experimental evidence from American farmers, one study showed an annual discount rate of $28 \%$ (Duquette et al. 2011). Lower discount rates have also been used (for example, Pagiola 1996 used a $10 \%$ discount rate for SLM practices in Kenya). Based on this, we use a discount rate of $25 \%$. But we also conduct sensitivity analysis of NPV and internal rate of return (IRR) by using discount rates of 10,25 , and $30 \%$ to determine robustness of the results. The sensitivity analysis of MRR is not conducted since this is not affected by the discount factor given that MRR is a ratio of net benefits and costs, both of which are discounted, hence canceling out the effect of the discount factor.

Farmers find it profitable to adopt an SLM practice if NPV $>0$. However, a given farmer's decision to adopt SLM practices typically does not take into account the off-site costs and benefits that result from adoption or nonadoption of SLM practices. The literature on these issues establishes that a positive NPV may be far from sufficient to induce investment (for example, Pender 1996; Dixit and Pindyck 1994; Fafchamps and Pender 1997). Hence, the MRR trend over the planning horizon will also be used to evaluate the change in attractiveness of SLM practices over time. For example, this analysis is likely to show a negative or small MRR at the beginning, after the initial large fixed costs of SLM are incurred. The MRR will improve over time as the large initial overhead investments decrease and their returns become more significant. Robustness of the MRR to the discount factor also will be computed using the three levels used for NPV, that is, $r=10,25$, and $30 \%$.

\section{Economic Data Used}

\section{Returns to SLM Practices}

For all three land use types (forests, croplands, and grazing lands), we assume that the land management practices recommended by the Ministry of Agriculture and Forests lead to SLM. So we use experimental results to determine the land production per hectare when farmers use or do not use SLM. We discuss each of the data sources under each land use type and corresponding to the six AEZs (Table 12.12). Other studies (for example, United Nations Environment Programme 2009) divide Bhutan into only three major agroclimatic zones, which are largely determined by altitude: (1) alpine zone (>4000 $\mathrm{m}$ ) — the alpine zone, where glaciers and glacial lakes are located, account for $10 \%$ of the total land area of Bhutan (Choden, et al. 2010); (2) temperate zone (1000-4000 m)-this zone lies in the middle belt; and (3) subtropical zone (200-1000 m) - this zone lies in the southern part (Choden et al. 2010). We will use the six AEZs (Table 12.12) since this reflects well the forest ecosystem that occupies the largest land area. 


\section{Cropland}

As discussed earlier, we focus only on maize, rice, and citrus. Data required for conducting returns to SLM practices are SLM practices and their impact on crop yield - that is, yield with and without SLM practices. We use experimental results from the Bhutan Overview of Conservation Approaches and Technologies (WOCAT) conducted by NSSC in collaboration with WOCAT to identify the SLM practices and their impact on maize and rice yields - that is, yield with SLM practices. The literature of past soil fertility studies also is used to determine crop yield with SLM practices. Yield obtained by farmers (BAU) was obtained from the 2011 RNR household survey data. Table 12.13 reports the SLM and yield under BAU.

\section{Maize}

For the major maize-growing zone - the dry subtropical zone, which runs from central to eastern Bhutan-the recommended SLM practices are ISFM with nitrogen, phosphorus, and potassium per hectare of 100, 80, and 60, respectively, plus 7 tons/ha farm yard manure (Chetri et al. 2003). With these inputs, the maize yield potential for improved varieties is 4.15 tons/ha (Chetri et al. 2003), while the farmer yield is only 2.79 tons/ha (RGoB and and MoA2011) or $67 \%$ of the yield potential. For a given crop, yield potential is the maximum yield of a crop under given agroecological characteristics (solar radiation, temperatures, soil characteristics, and so forth) and varietal characteristics (fraction of photosynthetic efficiency of converting biomass into economically important yield) (FAO 1996). Yield potential is used in studies determining yield gap and associated production constraints such as land degradation (for example, Licker et al. 2010).

\section{Rice}

Irrigated rice is grown in the humid (wet) and subhumid subtropics. ISFM is also recommended for irrigated rice with 7 tons/ha of farm yard manure and $17 \mathrm{~kg}$ of phosphorus/ha (Chetri et al. 2003). With ISFM and improved seeds, irrigated rice yield potential is 7 tons/ha (Chetri et al. 2003), but farmer yield is only 3.5 tons/ha (RGoB and MoA2009).

\section{Citrus}

The SLM practice used for oranges is to plant on fallow land, ex-tseri land (i.e. slash and burn) and on cropland where there is high risk of land degradation through soil and water erosion. About $23 \%$ of rural households reported that they had left their land fallow in the 2009 RNR survey (Christensen et al. 2012). Such land could be used for citrus production, and this could greatly contribute to reducing poverty since — as will be seen later — citrus is among the most profitable crops and, as discussed earlier, orchard production contributed $73.6 \%$ of crop GDP growth in 2000-2009 (Christensen et al. 2012) and $66 \%$ of household cash income. Planting pure stand citrus trees could be a challenge due to their long gestation period (six years), which investment smallholder farmers may not be able to afford. Using the farmer practice, oranges yield 10.7 tons/ha (FAOSTAT 2013). 


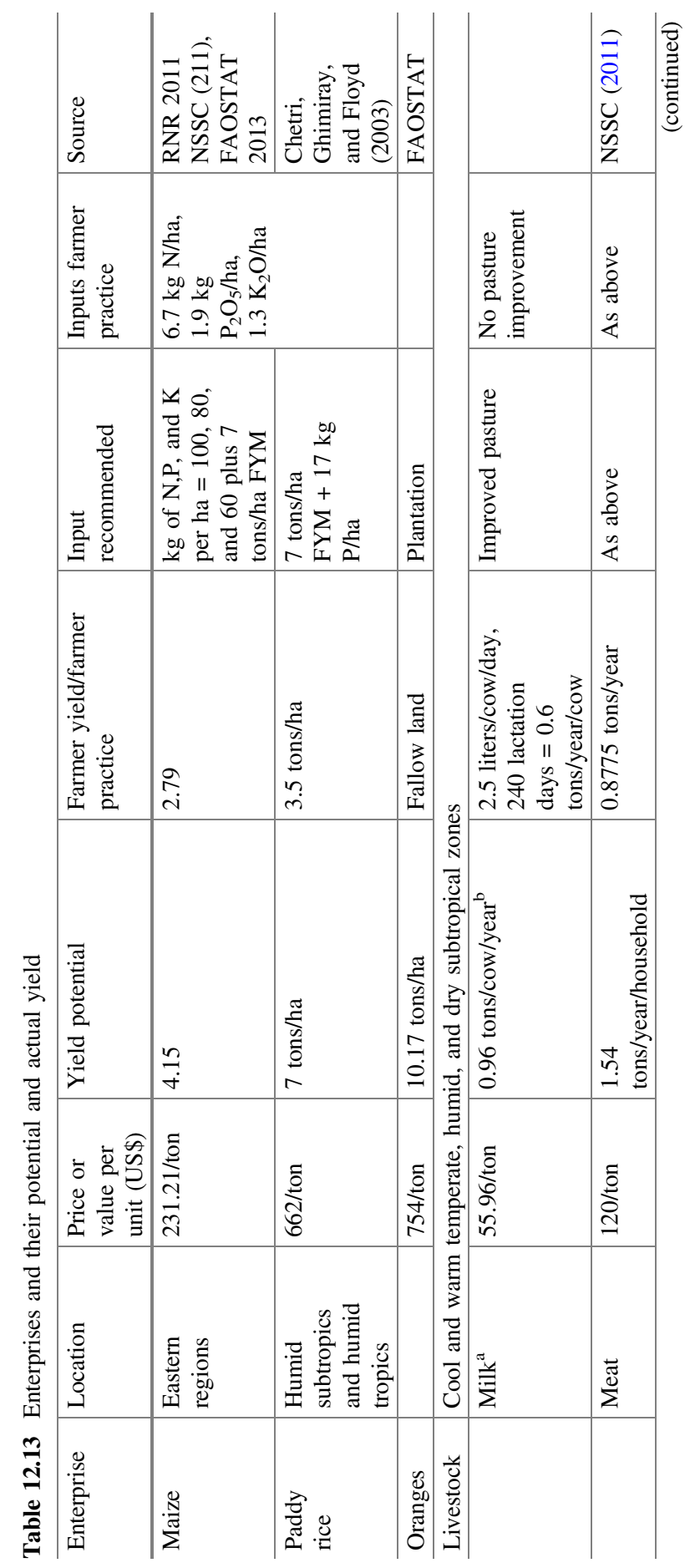




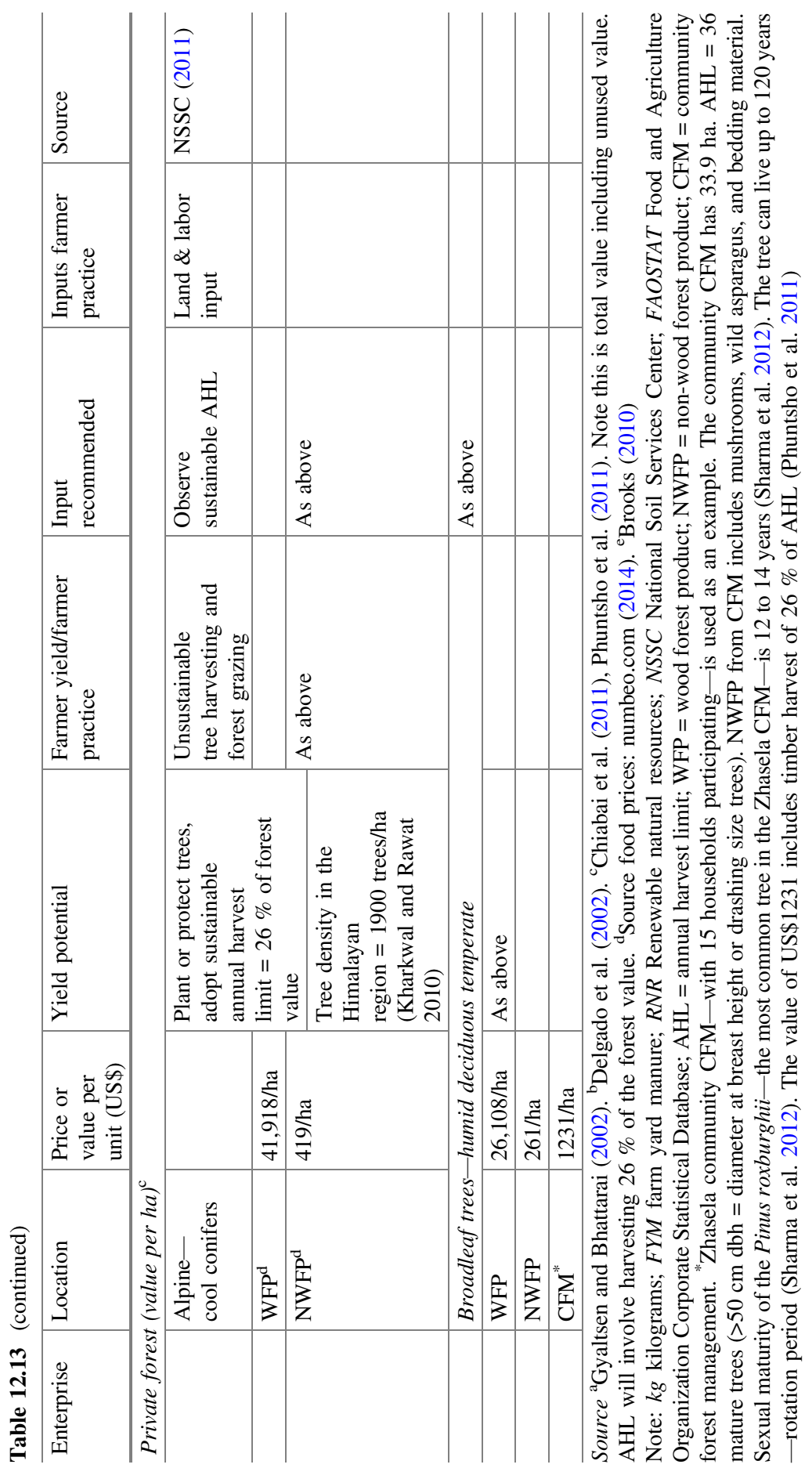




\section{Forest}

Forest plantations span all zones in Bhutan, and their productivity and value vary accordingly. Converting centrally managed non-PA forests to CFs and converting unused lands to CFs are the major SLM practices proposed to reduce soil erosion in HEP plants. A review by Bowler et al. (2010) showed that tree density under community-managed forests (CF) improved as compared to density under government management. For example, Agarwal (2009)'s study showed the forest density of CFs improved from the condition of CFs before in Nepal and India by 50 $\%$ and $36 \%$, respectively. The SWAT model results reflect the benefit of reduction of soil erosion due to planting trees on unused lands and increase in forest density. The value of other forest ecosystem services - timber, NTFP, and so forth - will also increase accordingly. To ensure that the forest value is relevant to the local economy, we will consider only ecosystem services that are felt at the national level. This includes water catchment, regulating services, timber and NTFP, and medicinal plants. It is well documented that the value of a forest differs depending on its use (for example, see Secretariat of the Convention on Biological Diversity 2001). Holding all else constant, forests closer to high population density have greater value than forests in remote areas (Pearce 2001). Forests used for tourism or those with rich biodiversity and other ecosystem values have higher values than those with lower ecosystem values (Secretariat of the Convention on Biological Diversity 2001). The private forests considered in this study are closer to human population and will have relatively higher values.

NTFP that are harvested from the forest include mushrooms, bamboo shoots, herbs, medicinal plants, canes, fodder, and loppings. For timber products, SLM is achieved when harvesting does not exceed the regeneration rate. The Ministry of Agriculture and Forests gives the annual harvest limit for each type of forest. For forest products, the sustainable annual harvest limit is determined using guidelines given by the Ministry of Agriculture and Forests.

\section{Grazing Land (Livestock Production)}

SLM for grazing land is improved pasture management - which includes planting leguminous seeds and improved grasses such as cocksfoot, Italian rye, and lotus (Samdup et al. 2013; Dorji 1993). It also includes rotational grazing on rangelands, which allows pasture to recover (Chophyel 2009). Improved pasture management could increase total digestible nutrient fivefold from 0.654 tons/ha for traditional pasture management (Dorji 1993) to 4.0 tons/ha (Roder et al. 2001). Improved pasture management can increase the live weight of livestock by up to $100 \%$. For example, a study in Australia showed that sowing pasture using improved pasture management increased cattle live weight 2.3 fold (Alcock and Hegarty 2006). NSSC (2011) showed that improved pasture management can increase livestock productivity between 50 and $100 \%$. We assume a minimum increase of $50 \%$ of livestock productivity if a farmer uses improved pasture management. Only $12 \%$ of farmers reported to have improved pastures. 
Meat production is about $51,000 \mathrm{mt}$ and $0.6 \mathrm{mt}$ per cow per year of milk (Wangdi 2012). This suggests each of the 58,120 households that own cattle (NSB and AsDB 2013) produce 0.8775 tons/year. Hence, with a $50 \%$ increase in livestock productivity, this will translate to 0.96 tons per cow/year of milk and 1.54 tons/year of beef per household.

Due to lack of livestock management data, a farmer was deemed to be using SLM if he or she reported use of improved pasture management. We use data from past studies to determine the different values of forest ecosystem services.

The next section discusses the results, starting with the land use change descriptive analysis, which reveals a 20-year pattern ranging from 1990 to 2010. This is followed by results on soil erosion analysis using SWAT modeling. The third section uses the results from the land use change analysis and the SWAT results to analyze the economic returns to SLM investments to address land degradation.

\section{Results}

\section{Land Use Change}

\section{Land Cover Change Classes}

We focus on four major land use types: forest, agricultural, pasture, and barren land. Table 12.14 describes the classification system used in this analysis and the interpretation of each class: deforestation and agricultural expansion. Two datasets were used to assess land cover change: The national land cover dataset was used to assess changes in pastureland, and an independently produced classified Landsat dataset was used to analyze other land cover changes. While methodological changes in the classification system between 1994 and 2010 precluded use of the

Table 12.14 Land cover change classes

\begin{tabular}{l|l|l}
\hline Deforestation & Agriculture Expansion & Agriculture Contraction \\
\hline - Forest to grassland or shrub & $\bullet$ Barren land to agriculture & $\begin{array}{l}\text { ・ Agriculture to unused } \\
\text { land }\end{array}$ \\
\hline - Forest to bare land & $\begin{array}{l}\text { • Grassland or shrubland to } \\
\text { agriculture }\end{array}$ & $\bullet$ Agriculture to forest \\
\hline - Forest to urban area & $\bullet$ Forest to agriculture & $\bullet$ Agriculture to urban area \\
\hline - Forest to agriculture & & \\
\hline Land Clearing & Pasture Expansion & Pasture Contraction \\
\hline $\begin{array}{l}\text { Agriculture, shrubland, or } \\
\text { grassland to barren land }\end{array}$ & $\bullet$ Forest to pasture & $\bullet$ Pasture to forest \\
\cline { 2 - 3 } & $\begin{array}{l}\text { - Grassland, shrubland, or } \\
\text { barren area to pasture }\end{array}$ & $\begin{array}{l}\text { Pasture to grass, } \\
\text { shrubland, or barren land }\end{array}$ \\
\hline & $\bullet$ Agriculture to pasture & $\bullet$ Pasture to agriculture \\
\hline
\end{tabular}

Source Authors 
national land cover dataset in much of the land cover change analysis, it was considered more reliable for static analyses and for diagnosing changes in pastureland, which is not separated from other grasslands in the Landsat data.

The vast majority of forested area remained as such between 1990 and 2010 . The minor deforestation that was present primarily consisted of a conversion from forest to grassland/shrubland or agriculture. Despite agriculture's being a primary player in the minor deforestation, as a whole, agricultural expansion occurred mostly in barren land, grassland, or shrubland. In fact, nearly as much agriculture was converted back to forested land as forest was to agriculture. For the time period analyzed, there was a net expansion in agriculture.

According to the land use change analysis conducted on the national dataset to assess pastureland expansion and contraction, pastureland as a whole is in slight decline. Although the dataset indicates a substantial conversion from agricultural land to pasture, it also demonstrates that twice as much pasture was converted to forested land. These conversions may be real observed trends, but they may also be spurious artifacts of the difference in methods between the 1994 dataset and the 2010 dataset. To assess the validity of the observed decline, independent land cover assessments were analyzed. FAO data indicate a stagnation in permanent meadows and pastureland while classified Landsat data from 1990 and 2010-produced independently from the national land cover dataset - indicate a significant decline in grasslands. While not all grasslands can be assumed to be pasture, the decline in grasslands in combination with the FAO data lends credence to the observed trend in the national land cover data.

\section{Impact of Land Use Change and Land Management on Soil Erosion}

\section{Sediment Results}

Using the SWAT model sediment algorithms, the landscape total sediment yield for BAU was calculated for each sub-basin, and the average annual result is presented in Fig. 12.16. Rainfall and runoff, drive the sediment process, it is obvious that higher sediment was observed at these high rainfall/runoff regions. However, land cover, slope, and soil erodibility factors play major roles in the sediment yield potential. In this case, Table 12.15 provides the distribution of hydrology and sediment yield by land use and corresponding slope and slope length combined factors. Most of the sediment was coming from higher elevations in the north of the country including the Chinese part of the watershed but also from the southernmost part of the watershed draining into India. In the northern part of the basins, sediment delivery is mainly due to high snowfall and snowmelt processes with steeper slopes. However, due to lack of quality soils data and poor soil scale (1: 1,000,000 scale) maps, the simulated outputs may contain large uncertainity. The sedimentation process has been going on for thousands of years, and most of the soils may have 


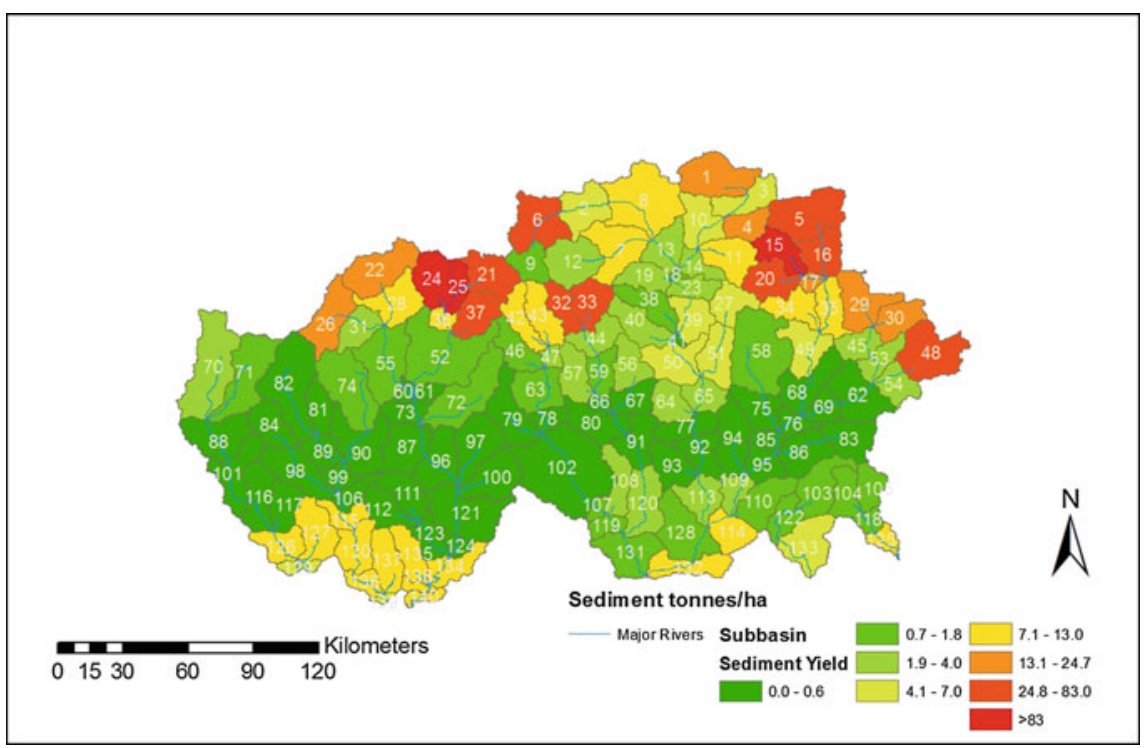

Fig. 12.16 Average annual (1997-2012) sediment load (tons per hectare) from each sub-basin. Source Hydromet data (1997-2010) and Author's calculation using Soil and water assessment tool results

been eroded already. But the sedimentary rocks in the higher altitudes with steep slopes can contribute to the sediment yields slowly over many years to come. The high volume of snow and runoff process due to glacier lake breaks, heavy boulders, rocks, and large aggregates may contribute to the sediment process. It is unlikely that small suspended particles are seen from these area, which is also evident from the observed sediment data collected by the Hydromet department.

During the field visit it was clear that there were several boulders and rocks removed from the river bottoms and stored on the side of the stream as protection from additional stream bank erosion in the large river sections and flat areas. The southern part of the watershed experiences very high rainfall during the monsoon season from June through October. The main sources of sediment are highly managed agriculture and urban development including road construction between various small to medium towns and across international trade. These exist along with a high slope area with barren and erodible land, and they contribute significant sediment loading to the rivers. The middle part of the watershed, where the rainfall is low and of less intensity, contributes little or no sediment and is also well covered by forest and grass on the ground to protect from any sediment contribution. Figure 12.17 shows the average annual sediment load from the entire basin simulation as 9.39 tons/ha/year during the simulation period f 2007-2012. It also shows that as the sediment reaches the flat areas, some of the sediment - up to $14 \%$ - may get deposited into the channels and river network, resulting in only about 8 


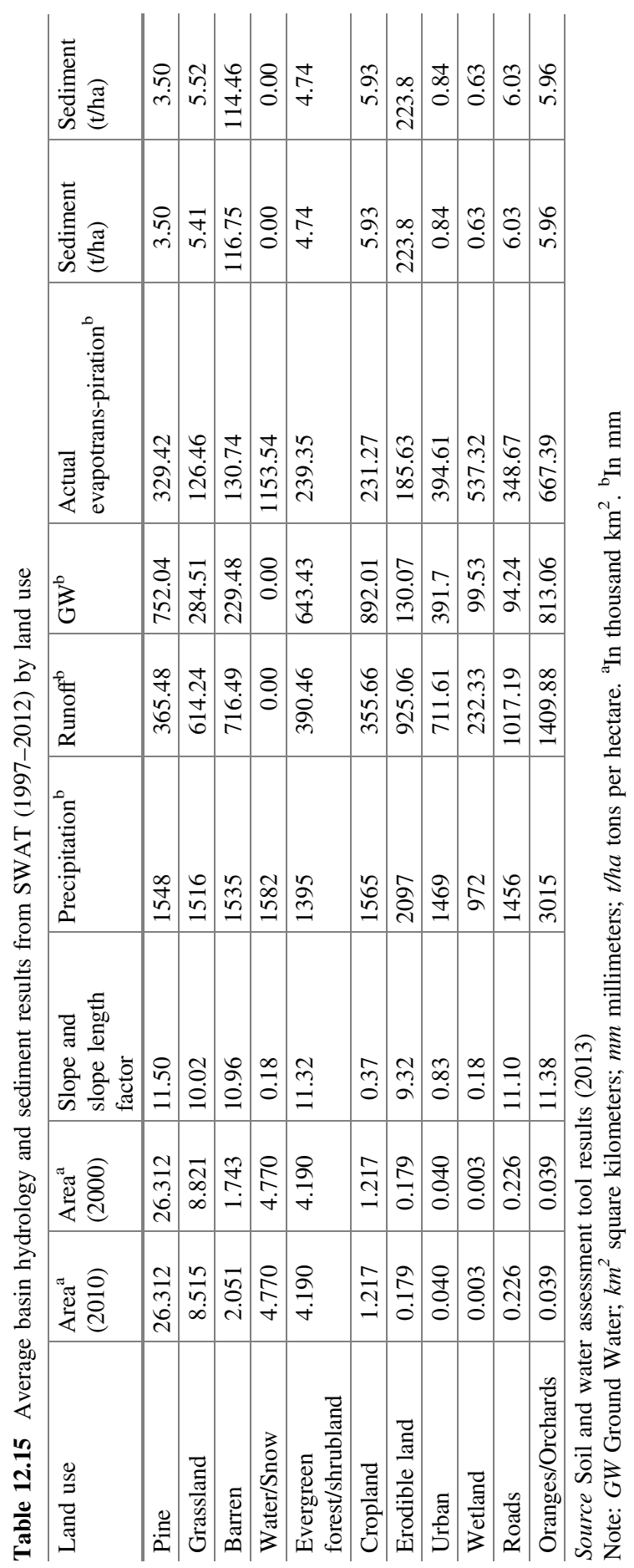




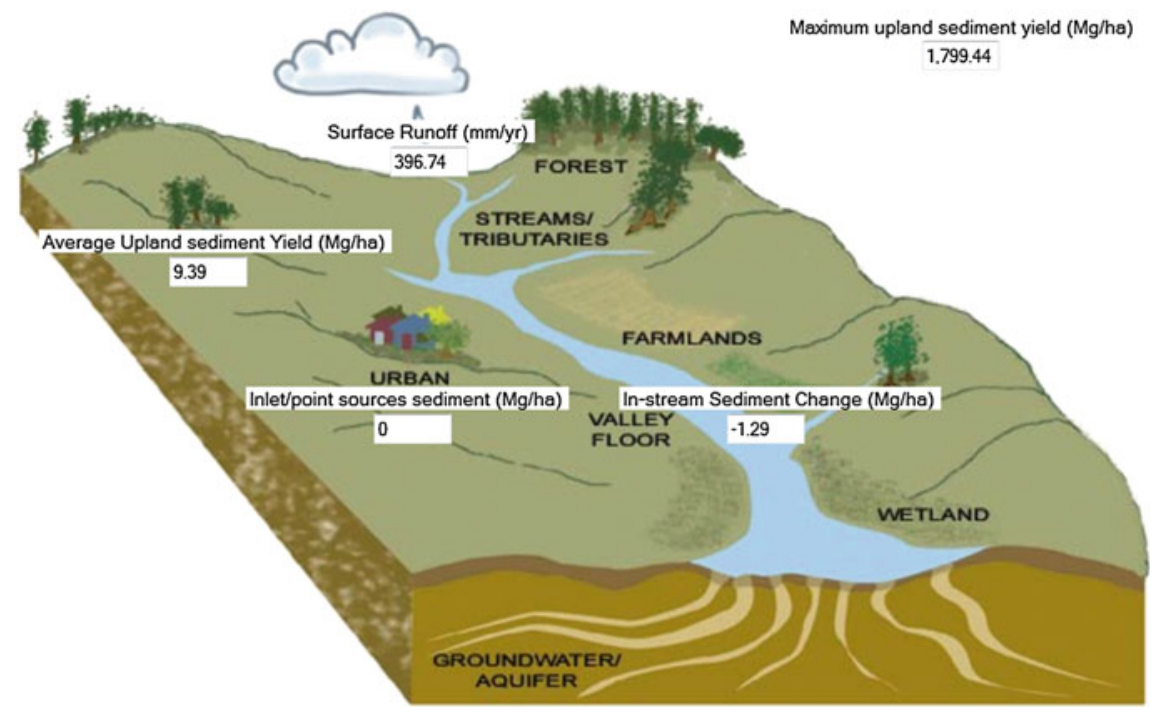

Fig. 12.17 Average sub-basin sediment load from the entire basin and sediment deposition in the stream for the entire period of the simulation (1997-2012). Source Authors. Note: $M g / h a$ megagram (ton) per hectare; $\mathrm{mm} / \mathrm{yr}$ millimeters per year

tons/ha/year of sediment leaving the watershed. However, the sediment delivery varies by each major river basin.

In addition, the land use change data between 2000 and 2010 were used in the model. The major changes observed were from grassland to brushland and barren land. Also in 2000 the percentage of barren land was less compared to 2010 by almost $10 \%$, with more grassland. With these changes the model predicted 8.61 tons/year, that is, about $8.3 \%$ less sediment in 2000 than the current land use based on 2010 data. This is mainly because there was less barren and highly erodible land in 2000 than now and these lands were covered by grassland that protected the soil surface. The overall 2000 land use area and corresponding sediment yield per ha is shown in Table 12.16. There were some landuse changes between 2000 and 2010 in the water/glacier/snow area. Most of this area was either grassland or barren land. Even though there was more water/glacier/snow area in 2000 than in 2010, this

Table 12.16 Basinwide annual average of sediment under sustainable land management program

\begin{tabular}{l|l|l|l|l}
\hline Land use & $\begin{array}{l}\text { Area (in } \\
\left.\mathrm{km}^{2}\right)\end{array}$ & $\begin{array}{l}\text { Sediment under } \\
\text { SLM (t/ha) }\end{array}$ & $\begin{array}{l}\text { Baseline } \\
\text { sediment }(\mathrm{t} / \mathrm{ha})\end{array}$ & $\begin{array}{l}\text { Percentage } \\
\text { change }\end{array}$ \\
\hline $\begin{array}{l}\text { High altitude } \\
\text { forestland }\end{array}$ & $26,311.71$ & 1.75 & 3.50 & 50 \\
\hline Cropland & 1216.65 & 4.58 & 5.93 & 23 \\
\hline Oranges/orchards & 38.64 & 2.98 & 5.96 & 50 \\
\hline
\end{tabular}

Source Soil and water assessment toolmodel results (year?)

Note: SLM Sustainable Land Management; $\mathrm{km}^{2}$ square kilometers; $t / h a$ tons per hectare 
could be due to the various remote sensing scenes used for classification that may be from the winter or spring seasons' snapshots. So this change was not included in the simulation.

With proper land management techniques such as contouring, increased forested cover and selection of proper plants, and terracing where possible for agricultural land, the SLM techniques were applied to only needle leaf forested land, cropland, and orange landscapes in the SWAT model, and the results are summarized in Table 12.16 and Fig. 12.18. Even though the expected reduction seems to be highas much as $50 \%$ erosion reduction - with the combination of various SLM techniques and long-term maintenance or caretaking, one can reach the reduction goal. However, the range of reduction certainly varies based on rainfall, intensity, landuse, slope, and soil condition from as low as $12-70 \%$. Also it is assumed all eligible land areas have adopted SLM practices. In practice, however, the adoption rate is lower and varies across space and time. What is reported in Table 12.16 is the potential impact of SLM that Bhutan can achieve if it fully implements its 2020 Vision.

It is important to compare our results with the results of other studies done in areas with comparable topography. Ziadat and Taimeh (2013) published results from field studies in arid regions where the steep slope, soil moisture, and land management can account for as much as $90 \%$ of the land degradation. Such land erosion can be avoided by as much as 50-60\% using proper land management techniques and preserving soil moisture with vegetation or ground cover. This is an arid region with less rain, but the intensity is high; it can be compared to humid,

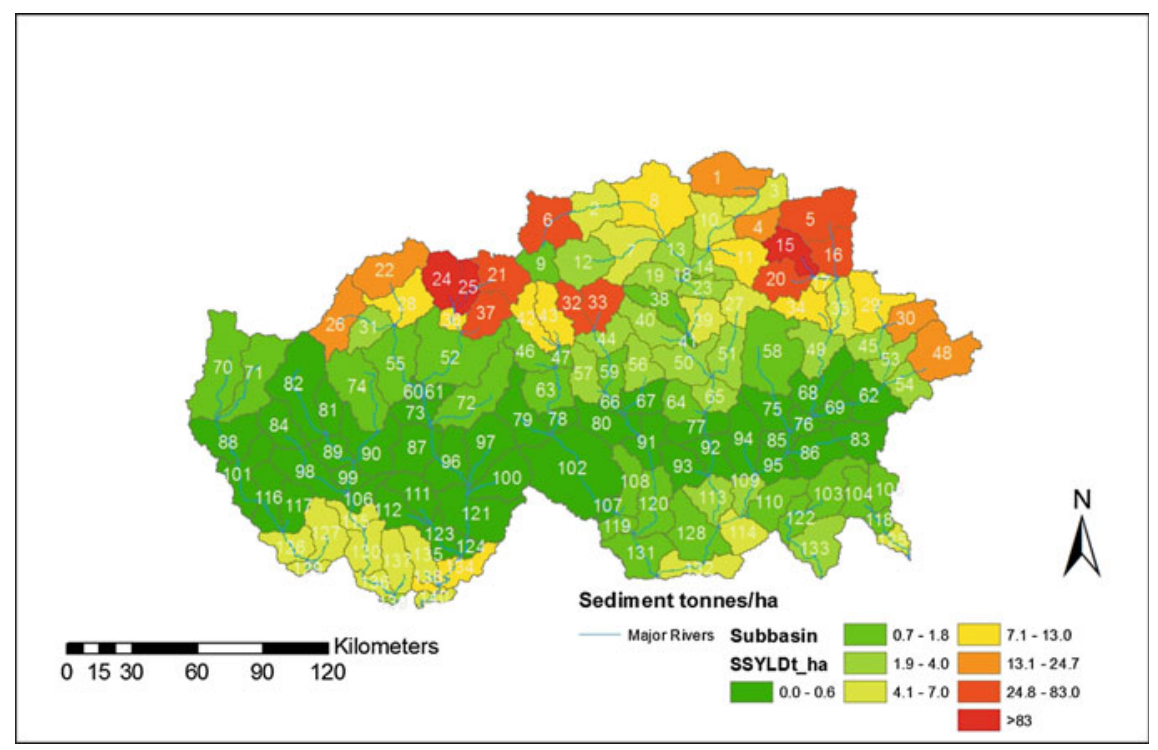

Fig. 12.18 Average annual (1997-2012) sediment load (t/ha) from each sub-basin under SLM scenarios. Source Author's calculation using the Soil and water assessment tool model results. Note: $t / h a$ tons per hectare; SLM Sustainable Land Management; SSYLDt_ha sediment load (t/ha) 
high-rainfall regions with soil moisture near saturation all the time, leading to similar outcomes. In addition, Ziadat et al. (2012) have published a technical report to show various agricultural land management measures in steep slopes and annual precipitation of about 700 to $1000 \mathrm{~mm}$ in Syria. The soil and water conservation practices used were stone bunds, stone walls, intercultivation, and other SLM techniques. The authors showed in real field measurements that the erosion can be reduced by as much as 55-60\% during a sustained long period with proper SLM techniques (Ziadat et al. 2012). Appendix 1 of the paper reports actual SLM practices and their impact on reducing soil erosion. The watershed where these were practiced is smaller, but the practices are promising. All these SLM techniques are documented qualitatively and in a simple way to understand by WOCAT and can be accessed at http://qt.wocat.net/qt_report.php.

The three SLM projects demonstrated are similar to what is experienced in Bhutan: high slopes, high rainfall, and forest degradation. Most of the benefits from the SLM techniques will be in the lower part of the watershed where agriculture is present, and improved land management will help greatly since this is where the rainfall is also high. Appropriate pine plantation management may also be helpful; however, pine plantations above the tree line, such as at $3800 \mathrm{~m}$ or above, will be not be beneficial.

\section{Economic Analysis of SLM}

\section{Use and Drivers of Adoption of SLM Practices}

The discussion below analyzes returns to SLM by focusing on three land use types: forest, grazing lands, and croplands. We focus this portion of our analysis on the interaction of livestock, fertilizer, and roads. To understand current SLM practices among land users, we analyze the 2009 RNR survey data.

Descriptive statistics and an econometric analysis of the data reveal that access to roads and livestock ownership significantly increase the quantity and type of fertilizer (inorganic or manure) applied by farmers (Tables 12.18 and 12.19). An analysis of the RNR survey data shows that only $31 \%$ of crop farmers use inorganic fertilizer and that it is the farmers closer to roads who are more likely to apply inorganic fertilizer. This result, which is robust across both the descriptive statistics and the econometric analysis, highlights the importance of roads in the delivery and use of inorganic fertilizer. Econometric results also show that farmers closer to roads have a higher propensity to use manure than those farther away from roads. No farmer reported to have used both inorganic fertilizer and manure-suggesting that farmers substitute inorganic fertilizer with manure or vice versa. It could also mean that farmers who do not own livestock can apply only inorganic fertilizer and that farmers do not see the need to apply both manure and inorganic fertilizer. As expected, livestock ownership increases propensity to use manure (Table 12.18). In addition, livestock and land ownership both increase the propensity to use all four 
Table 12.17 Share (percentage) of farmers who used inorganic and organic inputs

\begin{tabular}{|c|c|c|c|c|}
\hline Category & $\begin{array}{l}\text { Use inorganic } \\
\text { fertilizer }\end{array}$ & \begin{tabular}{|l} 
Use \\
manure
\end{tabular} & $\begin{array}{l}\text { Have private } \\
\text { forest }\end{array}$ & $\begin{array}{l}\text { Have improved } \\
\text { pastures }\end{array}$ \\
\hline $\begin{array}{l}\text { Nationally } \\
(N=57,705)\end{array}$ & 30.9 & 59.6 & 3.6 & 12.0 \\
\hline \multicolumn{5}{|l|}{ Distance to road } \\
\hline 0 & 19.2 & 69.2 & 0.0 & 0.0 \\
\hline Less than $1 \mathrm{~h}$ & 38.3 & 59.5 & 4.3 & 13.1 \\
\hline $1-3 \mathrm{~h}$ & 29.9 & 68.0 & 3.1 & 9.4 \\
\hline $3-6 \mathrm{~h}$ & 27.1 & 62.5 & 2.6 & 13 \\
\hline $6 \mathrm{~h}-1$ day & 17.5 & 57.5 & 2.1 & 13 \\
\hline$>1$ day & 7.0 & 43.8 & 2.9 & 9.3 \\
\hline \multicolumn{5}{|l|}{ Land owned } \\
\hline Land-poor tercile & 35.7 & 57.9 & 3.1 & 9.8 \\
\hline Land-rich tercile & 25.9 & 61.4 & 4.2 & 14.3 \\
\hline
\end{tabular}

Source RNR household survey (2009)

Table 12.18 Drivers of propensity to use sustainable land management practices (marginal effects)

\begin{tabular}{l|l|l|l|l}
\hline Driver & Manure & Urea & Private Forest & Improved Pasture \\
\hline Land tenure/method of acquisition (cf. renting) \\
\hline - Own land & $0.025^{* * *}$ & $0.002^{* * *}$ & $0.008^{* * *}$ & $0.012^{* * *}$ \\
\hline - Leased out land & $-0.028^{* * *}$ & $-0.003^{* *}$ & $0.021^{* *}$ & 0.001 \\
\hline - Leased in land & $0.009^{* * *}$ & 0.000 & -0.002 & $-0.017^{* *}$ \\
\hline - Fallow land & $-0.014^{* * *}$ & 0.000 & $0.007^{*}$ & $0.009^{* * *}$ \\
\hline Own livestock cattle & $1.363^{* * *}$ & $0.119^{* * *}$ & $0.259^{* * *}$ & $0.992^{* * *}$ \\
\hline Own donkey & $0.246^{* *}$ & 0.006 & $0.423^{* * *}$ & $0.220^{*}$ \\
\hline Own horse & 0.006 & 0.000 & -0.012 & $0.249^{* * *}$ \\
\hline Age of respondent & 0.000 & $-0.000^{* * *}$ & $0.002^{* * *}$ & 0.001 \\
\hline Male respondent sex & -0.006 & $-0.010^{* * *}$ & $0.094^{* * *}$ & $0.096^{* * *}$ \\
\hline Time to Road (cf. more than one day) & $0.268^{* * *}$ & $0.128^{* * *}$ & $0.160^{* * *}$ & $0.344^{* * *}$ \\
\hline - Less than one hour & $0.359^{* * *}$ & $0.085^{* * *}$ & 0.038 & $0.140^{* * *}$ \\
\hline - One to three hours & $0.344^{* * *}$ & $0.082^{* * *}$ & $-0.087^{*}$ & $0.244^{* * *}$ \\
\hline - Three to six hours & $0.305^{* * *}$ & $0.034^{* * *}$ & $-0.152^{* * *}$ & $0.313^{* * *}$ \\
\hline - Six hours to one day & \multicolumn{5}{|l}{} \\
\hline Time to extension services $(c f$. more than one day) & $0.330^{* * *}$ \\
\hline - Less than one hour & $-0.273^{* * *}$ & $0.089^{* * *}$ & $0.151^{* *}$ & $0.289^{* * *}$ \\
\hline - One to three hours & $-0.147^{* * *}$ & $0.064^{* * *}$ & $0.135^{* * *}$ & $0.277^{* * *}$ \\
\hline - Three to six hours & $-0.149^{* * *}$ & $0.064^{* * *}$ & 0.092 & $0.148^{* * *}$ \\
\hline - Six hours to one day & $-0.228^{* * *}$ & $0.021^{* *}$ & 0.016 & $-1.590^{* * *}$ \\
\hline Constant & $-0.845^{* * *}$ & $0.426^{* * *}$ & $-2.379^{* * *}$ & \\
\hline
\end{tabular}

Source Computed from RNR survey data (2009)

Note: Dash in the "Driver" column indicates that the variable is part of a multi-part variable. ${ }^{*} p=0.10 .{ }^{* *} p=0.05 . * * * p=0.01$ 
Table 12.19 Returns to sustainable land management practices

\begin{tabular}{l|l|l|l|l|l|l|l}
\hline & \multicolumn{3}{|l|}{ Internal rate of return } & \multicolumn{3}{l}{ BCR } & \multicolumn{3}{l}{30 -year total NPV (US dollars) } \\
per hectare
\end{tabular}

Source Author's calculations

Note: $N P V$ net present value; BCR 30-year average benefit-cost ratio; ISFM integrated soil fertility management (combination of inorganic fertilizer and organic inputs)

SLM practices reported (manure, urea, private forest, and improved pasture). With the exception of manure use, access to extension services also increases the propensity to use all SLM practices - as expected. The results underscore the importance of rural services in enhancing SLM practices in Bhutan (Table 12.17).

Constraints to access to rural services and other important drivers of adoption of SLM could lead to unexpected farmer behavior. We examined the relationship between profitability and returns to land management practices.

\section{Returns to SLM Practices}

Equation 12.4 summarizes the returns to SLM for the enterprises considered. To check robustness of results to farmer discount factor, NPV and IRR are reported at discount factors of 10,25 , and $30 \%$. NPV $>0$ and IRR $\geq 0.12$ are considered the minimum requirements for adoption of SLM.

Results show that a citrus orchard is the most profitable enterprise, but it requires farmers to wait for at least six years before the first harvest. Such a prolonged period 
of time could be a challenge for smallholder farmers to be engaged in citrus production on a large scale. An amenable approach could be producing citrus on a small piece of land or planting trees in annual crops and planting them on fallow land. Profitability of citrus is robust across all three discount factors since both NPV and IRR remain higher or closer to the minimum level deemed economically desirable for farmers to grow citrus. Given this profitability, it is not surprising to see that the production of citrus and other horticultural crops and their contribution to household income has been increasing tremendously while the contribution of cereal crops to household cash income has been declining. Improved pasture management is the second most profitable enterprise - underscoring the potential role it can play in meeting the growing demand for livestock products as household income increases. Both NPV and IRR are robust across the three discount factors and significantly greater than their corresponding minimum levels. This suggests that adoption of improved pasture is an attractive SLM practice, and its adoption is enhanced by access to rural services (roads and extension services), secure land tenure, and number of livestock owned. Likewise, NPV and IRR for maize and rice are robust across the discount factor and greater than the minimum level, suggesting ISFM is an attractive SLM practice for two crops. NPV and IRR for private forests under CFM are both positive, but IRR for $r=25 \%$ and $r=30 \%$ are both below the minimum IRR of $12 \%$-suggesting that CFM may not compete favorably with other enterprises. However, CFM remains attractive for areas unfavorable to crop or livestock production. NPV for $r=10 \%$ for publicly owned pine and broadleaf forests is greater than zero, but the corresponding IRR is about zero-hence not likely to attract private investment to increase forest density or replant deforested areas. NPV and IRR for $r=25 \%$ and $r=30 \%$ are negative, suggesting private investment in enhancement of pine and broadleaf forests is not economically attractive and will require payment for ecosystem services to motivate communities to engage in improvement of forest resources.

\section{The Unholy Cross}

We analyzed the relationship between the adoption of land management practices (Table 12.17) and their returns (Table 12.19). The results show an inverse relationship - that is, the greater the returns to land management, the lower is the corresponding adoption rate. Such an "unholy cross" is due to constraints to adoption of high returns. For example, farmers away from roads may not be able to adopt inorganic fertilizer even when their returns are higher than nonuse of fertilizer. Likewise, the negative relationship between manure application and access to extension suggests lack of or limited advisory services on organic soil fertility management practices. This could mean that extension agents do not advise farmers to use organic soil fertility management in combination with inorganic fertilizers (ISFM), which has greater returns than use of fertilizer alone.

We now turn our analysis to the national level by extrapolating the per-hectare results to each zone and consequently to the whole country. When calculating 
Table 12.20 On-farm and off-farm benefits of action and cost of inaction against land degradation in Bhutan

\begin{tabular}{l|l|l|l}
\hline Land Type & $\begin{array}{l}\text { Annual (in NPV } \\
\text { USdollars per } \\
\text { hectare) }\end{array}$ & $\begin{array}{l}\text { Area (in } \\
\text { thousands of } \\
\text { hectares) }\end{array}$ & $\begin{array}{l}\text { Total benefit/loss } \\
\text { (in million US } \\
\text { dollars) }\end{array}$ \\
\hline
\end{tabular}

Forest

\begin{tabular}{l|l|l|c}
\hline \multicolumn{2}{l|}{ On-farm benefits (millions of US dollars) of SLM } & & \\
\hline - Cool broadleaf forest & 9.98 & 34.80 & 0.35 \\
\hline - Warm broadleaf & 6.98 & 1685.00 & 11.76 \\
\hline - Mixed conifer forest & 27.43 & 612.90 & 16.81 \\
\hline $\begin{array}{l}\text { - Chir pine (Pinus roxburghii) and } \\
\text { fir pine }\end{array}$ & 29.58 & 294.10 & 8.70 \\
\hline - Blue pine forest & 37.48 & 78.30 & 2.94 \\
\hline $\begin{array}{l}\text { - Total on-farm direct benefit from } \\
\text { forests }\end{array}$ & & & 40.56 \\
\hline $\begin{array}{l}\text { Loss due to deforestation and } \\
\text { reduced forest density (25\% of } \\
\text { on-farm benefit) }\end{array}$ & & & 10.14 \\
\hline $\begin{array}{l}\text { Off-site benefit-50 \% reduction } \\
\text { of sediment loading }\end{array}$ & & & 7.80 \\
\hline
\end{tabular}

Cropland

\begin{tabular}{l|l|l|l}
\hline - Maize & 119.28 & 28,641 & 3.42 \\
\hline - Rice & 263.89 & 24,357 & 6.43 \\
\hline $\begin{array}{l}\text {-Off-site benefit-sediment } \\
\text { reduction due to SLM on cropland } \\
\text { and grassland }\end{array}$ & & & 0.15 \\
\hline $\begin{array}{l}\text { Benefits of SLM on livestock } \\
\text { production }\end{array}$ & & & 17.85 \\
\hline
\end{tabular}

Total benefit of SLM

\begin{tabular}{l|l|l}
\hline - On-farm & & \\
\hline - Off-site & & 37.83 \\
\hline Change in GDP due to SLM & & 7.95 \\
\hline
\end{tabular}

Source Author's calculations

Note: SLM sustainable land management; GDP gross domestic product. ${ }^{a}$ Forest contributed $24 \%$ of the agricultural GDP - which was US\$284.73 million in 2012. This means the value of harvesting considered in the GDP calculation (US\$68.33 million) was greater than our estimates. ${ }^{\mathrm{b}}$ See Table 6.3. Druk Green Power Company spends US\$16 million each year to repair turbines and other underwater structures due to sediment loading. About $60 \%$ of such cost is associated with sediment loading

national scale returns, however, it is important to account for both on-site and off-site benefits. The results from the land use analysis and SWAT are also used to compute the off-site values of both forests and crops reported in Table 12.20. The computations are according to Eq. 12.6 and corresponding extrapolation to the national level. The calculations are done assuming $r=10 \%$ since the national-level social planning discount factor is lower than the private discount factor (Rambaud 
and Torrecillas 2007). The results assessing returns to SLM at a national scale show that adopting SLM could increase Bhutan's GDP by at least $2.5 \%$, a level that can be achieved if certain socioeconomic conditions are taken into account. However, it is important to note that a significant portion of the benefits accrue off-site, particularly for SFM. This is unsurprising given the role that forests play in reducing sediment loading to rivers and therefore HEP plants (Table 12.20).

\section{Study Limitations and Gaps}

Due to the short time and small budget of the project, we heavily relied on existing data. This was especially crucial given the national-level analysis done in this study. The heavy reliance on secondary data led to using second-best secondary data. We benefited from a large database from a number of institutions discussed in the Methodological Analysis and Data section, yet there were some key data gaps that hampered analysis. For example, the RNR household survey did not collect some important data required to determine the farmer land management practices and household-level characteristics. For the land use analysis, the data for the Bhutan Land Cover Assessment covering the 1994-2010 period had several issues. The data sources, classification, and methods differed between the data collected in 1994 and that collected in 2010, and this made computation of land use change less reliable. Unlike the 1994 dataset, the 2010 dataset was rigorously conducted with extensive ground truthing, an aspect missing from the Landsat dataset. This led to heavy reliance on Landsat data, which were consistently collected between the two time periods but were not ground-truthed.

For the SWAT modeling data, the elevation data at $10 \mathrm{~m}$ has lots of noise including a high unrealistic slope estimation due to a high difference in adjacent pixels. Slope is an important and significant factor in estimating sediment. In addition, land use is based on broad categories such as pine and broadleaf areas, but no data exist about the density or age of these plantations, which can also affect the sediment loads from these lands. In several areas there have been mudslides, forest fires, and so forth; these were not captured in the landuse map. Also, the landuse map was created using 2010 satellite images, which were run from 1997 to 2012, so the map may not represent landuse in the watershed for the entire time period of the simulation. There was concern about the impact of road construction on sediment loading, but no data were collected to measure such impact. This hampered inclusion of soil erosion due to road, house, and other types of construction.

Soils have significant limitations; for example, the scale of FAO soils data is 1:1,000,000, and its parameters are not measured-just estimated based on global soil properties and pedo-transfer functions - which may not capture the local metamorphism and erodibility factors properly. Finally, most of the rainfall and temperature gauge data were gathered in the lower altitudes, typically less than $3000 \mathrm{~m}$. However, much of the watershed covers higher than $3000 \mathrm{~m}$ of elevation, even though elevation correction for temperature and precipitation was used as an 
input to the model; the spatial variability of these parameters is not captured due to lack of any knowledge or field data. In addition, there are many months and years of data that were missing in the precipitation gauges, and those were estimated with SWAT's built-in weather generator using the historical statistics generated by Climate Forecast System Reanalysis global weather data. Despite these limitations and gaps, this study provides empirical evidence that has important policy implications. The next section summarizes the policy implications of the study.

\section{Implications of the Results}

Bhutan's economy is heavily dependent on generation of HEP, and the country's efforts to achieve SLM are justified by our findings, which show that the adoption of SFM could reduce the cost of sediment loading by $50 \%$.

Results show that a citrus orchard is the most profitable enterprise, but its long gestation period is a hindrance to large-scale investment. Given the growing demand for citrus and horticultural crops, there is need of increasing efforts to promote citrus and horticultural crop production in a manner that is amenable among smallholder farmers. Producing citrus fruits on a small piece of land or planting citrus trees in annual crops could lead to significant production that does not burden farmers to set a large piece of land and wait for six years before the first harvest. The increasing production of fruits and horticultural crops could be accelerated by enhancing nurseries and extension services that provide both production and marketing advisory services.

Returns to CFM are low but profitable at a lower discount rate. This means CFM may not compete with annual crops or livestock but is still favorable for abandoned areas. Likewise, investment in pine and broadleaf forests is profitable at high discount factors, which suggests the importance of enhancing incentives of communities to engage in CF programs by payment for ecosystem services. As our results show, SFM can reduce sediment loading to rivers serving HEP plants by $50 \%$. This justifies improvement of the current payment for ecosystem services program in which DGPC pays about $1 \%$ of its revenue to the government to encourage farmers to adopt SLM and SFM. Because such money is given to the government, which in turn uses the money to provide advisory services, it is hard for farmers to connect DGPC payments and the DGPC-funded advisory services provided by the government. There is great need for designing a policy that will give DGPC a mandate to interact directly with land users. DGPC has actually requested RGoB's permission to work with farmers directly, but this has not yet been approved. This could be enhanced under a CF program by allocating the forest currently under government control to communities, which in turn will increase forest density and contribute to reducing sediment loading. Instead DGPC is currently implementing corporate responsibility programs such as planting trees and supporting communities to take up environmentally friendly practices. For example, tree planting is 
done between Paro and Chhukha dam. In addition, around each of the HEP plants, DGPC is supporting green and clean programs.

Considering the drivers of SLM, we see that land security, access to extension services, and roads will enhance SLM and will have multiplier effects. RGoB has already started investing heavily in improving rural roads. However, road construction has contributed to increasing sediment loading. This suggests the need for adopting sustainable road construction that minimizes soil erosion.

In summary, Bhutan's policies and its cultural and historical background have set the country on the path to becoming a global green growth success story. Results of this study vindicate the country's efforts to invest in sustainable land and forest management.

Open Access This chapter is distributed under the terms of the Creative Commons Attribution Noncommercial License, which permits any noncommercial use, distribution, and reproduction in any medium, provided the original author(s) and source are credited.

\section{References}

Agarwal, B. (2009). Gender and forest conservation: The impact of women's participation in community forest governance. Ecological Economics, 68, 2785-2799.

Alcock, D., \& Hegarty, R. S. (2006). Effects of pasture improvement on productivity, gross margin and methane emissions of a grazing sheep enterprise. International Congress Series, 1293, 103-106.

Arnold, J. G., Srinivasan, R., Muttiah, R. S., \& Williams, J. R. (1998). Large-area hydrologic modeling and assessment: Part I. model development. Journal of American Water Resources Association, 34(1), 73-89.

Barrett, C. B., Place, F., \& Aboud, A. (2002). The challenges of stimulating adoption of improved natural resource management practices in African agriculture. In C. B. Barrett, F. Place, \& A. A. Aboud (Eds.), Natural resources management in African agriculture (pp. 1-22). Nairobi, Kenya: World Agroforestry Centreand CAB International.

Beldring, S., \& Voksø, A. (2011). Report No. 4-2011: Climate change impacts on the flow regimes of rivers in Bhutan and possible consequences for hydropower development. Oslo, Norway: Norwegian Water Resources and Energy Directorate. ISSN: 1502-3540.

Berry, L., Olson, J., \& Campbell, D. (2003). Assessing the extent, cost and impact of land degradation at the national level: Finding and lessons learned from seven pilot case studies. New York: Global Mechanism, United Nations.

Bowler, D., Buyung-Ali, L., Healey, J. R., Jones, J. P. G., Knight, T., \& Pullin, A. S. (2010). The evidence base for community forest management as a mechanism for supplying global environmental benefits and improving local welfare. CEE Review 08-011. Bangor, UK:Centre for Evidence-Based Conservation.

Brooks, J. S. (2010). The Buddha mushroom: Conservation behavior and the development of institutions in Bhutan. Ecological Economics, 69, 779-795.

Chetri, G. B., Ghimiray, M., \& Floyd, C. N. (2003). Effects of farmyard manure, fertilizers and green manuring in rice-wheat systems in Bhutan: Results from a long-term experiment. Experimental Agriculture, 39, 129-144.

Chiabai, A., Travisi, C. M., Markandya, A., Ding, H., \& Nunes, P. A. L. D. (2011). Economic assessment of forest ecosystem services losses: Cost of policy inaction. Environmental \& Resource Economics, 50, 405-445. 
Choden, S., Tashi, S., \& Dhendup, N. (2010). Analysis of the contributions of protected areas to the social and economic development of Bhutan at national level. Thimphu, Bhutan: Ministry of Agriculture and Forests, Royal Government of Bhutan.

Chophyel, P. (2009). Rangeland management in Bhutan: A consultancy report. Thimphu, Bhutan: Royal Government of Bhutan, Ministry of Agriculture.

Christensen, G., Fileccia, T., \& Gulliver, A. (2012). Bhutan. Agricultural sector review, Vol. 1, Issues, Institutions and Policies. Rome: FAO; Washington, DC: World Bank.

D’Exelle, B., van Campenhout, B., \& Lecoutere, E. (2012). Modernisation and time preferences in Tanzania: Evidence from a large-scale elicitation exercise. Journal of Development Studies, 48 (4), 564-580.

Delgado, C., Narrod, C., \& Tiongco, M. (2002). Policy, technical, and environmental determinants and implications of the scaling-up of livestock production in four fast-growing developing countries: A synthesis. FAO: Final Research Report of Phase II. Rome.

DGPC (Drik Green Power Coroporation). (2009). Druk green power limited. Thimphu: Brochure.

Dixit, A. K., \& Pindyck, R. S. (1994). Investment under uncertainty. Princeton, NJ: Princeton UniversityPress.

Dorji, J. (1993). Estimation of grazing animal feed requirement in the kingdom of Bhutan. Thimphu, Bhutan: Royal Government of Bhutan, National Environment Commission.

Duflo, E., Mullainathan, S., \& Bertrand, M. (2004). How much should we trust difference-in-difference estimates? Quarterly Journal of Economics, 119(1), 249-275.

Dukra, K. (2013). Bhutan RNR statistics 2012. Thimphu, Bhutan: Royal Government of Bhutan, Ministry of Agriculture and Forests.

Duquette, E., Higgins, N., \& Horowitz, J. (2011). Farmer discount rates: Experimental evidence. American Journal of Agricultural Economics, 94(2), 451-456.

Fafchamps, M., \& Pender, J. (1997). Precautionary saving, credit constraints, and irreversible investment: Theory and evidence from semiarid India. Journal of Business and Economic Statistics, 15(2), 180-194.

FAO (Food and Agriculture Organization of the United Nations). (1996). Agro-ecological zoning guidelines. FAO Soils Bulletin 73. Rome. www.fao.org/docrep/w2962e/w2962e00.htm\#P-2

FAO (Food and Agriculture Organization of the United Nations). (2011). State of the world's forests food. Accessed 21 Mar 2014. www.fao.org/forestry

FAO (Food and Agriculture Organization of the United Nations). (2013). FAOSTAT database. Accessed 21 Mar 2014. http://faostat3.fao.org/faostat-gateway/go/to/home/E

FAO/UNESCO. (1977). Soil Map of the world (Vol. VI). Paris: Africa. Unesco.

Flay, R. B. (2001). Modeling nitrates and phosphates in agricultural watersheds with the soil and water assessment tool. Accessed 22 2006. www.waterscape.org/pubs/tech_swat/SWAT_ Review.doc

Gardner, K., \& Barrows, R. (1985). The impact of soil conservation investments on land prices. American Journal of Agricultural Economics, 67(5), 943-947.

GEF (Global Environment Facility). (2012). Bhutan sustainable land management. Accessed 15 Jan 2014. www.thegef.org/gef/greenline/january-2012/bhutan-sustainable-land-management

Gupta, H. V., Sorooshian, S., \& Yapo, P. O. (1999). Status of automatic calibration for hydrologic models: Comparison with multilevel expert calibration. Journal of Hydrologic Engineering, $4(2), 135-143$.

Gyaltsen, T., \& Bhattarai, B. N. (2002). Cattle migration system of western Bhutan: A case study. Rome: FAO. www.fao.org/ag/agp/AGPC/doc/pasture/peshawarproceedings/cattlemigration. pdf

Gyamtsho, P., Singh, B. K., \& Rasul, G. (2006). Capitalisation and sharing of experiences on the interaction between forest policies and land use patterns in Asia: Linking people with resources. Technical Paper. Kathmandu, Nepal: International Centre for Integrated Mountain Development.

Hein, L. (2006). Environmental economics tool kit: Analyzing the economic costs of land degradation and the benefits of sustainable land management. Wageningen, The Netherlands: United Nations and Global Environment Fund. 
Heisey, P. W., \& Mwangi, W. (1998). Fertilizer use and maize production in Sub-Saharan Africa. CIMMYT Economics Working Paper 96-01. Mexico City, Mexico: International Maize and Wheat Improvement Center.

Hydromet. Various years. Hydrological and meteorological raw data. Accessed 30 June 2014. www.moea.gov.bt/departments/department.php?id=4

IPCC (Intergovernmental Panel on Climate Change). (2012). Renewable energy sources and climate change mitigation special report of the intergovernmental panel on climate change. Cambridge, UK: Cambridge University Press.

Licker, R. M., Johnston, J. A., Foley, C., Barford, C. J., Kucharik, C., \& Monfreda, Ramankutty N. (2010). Mind the gap: How do climate and agricultural management explain the 'yield gap' of croplands around the world? Global Ecology and Biogeography, 19(6), 769-782.

Luzio, M., Srinivasan, R., \& Arnold, J. G. (2002). Integration of watershed tools and SWAT model into BASINS. Journal of American Water Resource Association, 38(4), 1127-1141.

Lysne, D., Glover, B., Stole, H., \& Tesakar, E. (2003). Hydraulic design. Publication No. 8. Trondheim. Norway: Norwegian Institute of Technology.

MoAF. (2011). Agriculture survey 2011 Dzongkhag level statistics (Vol. 1). Thimphu, Bhutan: Ministry of Agriculture and Forests.

MoAF (Ministry of Agriculture and Forests). (2010). Bhutan land cover mapping. Online at http:// www.rspnbhutan.org/news-and-events/news/301-bhutans-land-cover-maps-updated.html. Accessed 28 July 2014.

Moriasi, D. N., Arnold, J. G., Van Liew, M. W., Bingner, R. L., Harmel, R. D., \& Veith, T. L. (2007). Model evaluation guidelines for systematic quantification of accuracy in watershed simulations. ASABE, 50(3), 885-900.

Mukherjee, C., White, H., \& Wuyts, M. (1998). Econometrics and data analysis for developing countries. London: Routledge.

Nandwa, S. M., \& Bekunda, M. A. (1998). Research on nutrient flows and balances in East and Southern Africa: State-of-the-art. Agriculture, Ecosystems \& Environment, 71, 5-18.

Nash, J. E., \& Sutcliffe, J. V. (1970). River flow forecasting through conceptual models: Part I. A discussion of principles. Journal of Hydrology, 10(3), 190-282.

National Statistical Bureau (NSB). (2009). National accounts statistics: 2000-2008. National Statistical Bureau. ThimphuNational Statistical Bureau (NSB). 2012. National Accounts Statistics. National Statistical Bureau. Thimphu.

National Statistical Bureau and Asian Development Bank. (2013). Bhutan living standards survey 2012 report.www.nsb.gov.bt/publication/files/pub1tm2120wp.pdf

NSSC (National Soil Services Center). (2011). BHUCAT. Bhutan catalogue of soil and water conservation approaches and technologies. Best practices and guidelines from Bhutan for sustainable land management on steep to very steep slopes. Thimphu, Bhutan: Department of Agriculture, Ministry of Agriculture and Forests, Royal Government of Bhutan. www.nssc. gov.bt

Numbeo.com. (2014). Food prices in Bhutan. www.numbeo.com/food-prices/country_result.jsp? country=Bhutan. Accessed 15 May 2014.

Pagiola, S. (1996). Price policy and returns to soil conservation in semi-arid Kenya. Environmental \& Resource Economics, 8, 255-271.

Pearce, D. W. (2001). The economic value of forest ecosystems. Ecosystem health, 7(4), 284-296.

Pender, J. (1996). Discount rates and credit markets: Theory and evidence from rural India. Journal of Development Economics, 50, 257-296.

Phuntsho, S., Schmidt, K., Kuyakanon, R., \& Temphel, K. J. (Eds.). (2011). Community forestry in Bhutan: Putting people at the heart of poverty reduction. Thimphu, Bhutan: Ministry of Agriculture and Forests.

Rambaud, S. C., \& Torrecillas, M. J. (2007). Some considerations on the social discount rate. Environmental Science \& Policy, 8(4), 343-355.

RGoB (Royal Government of Bhutan). (2002). Bhutan 2020: A vision for peace. Thimphu, Bhutan: Prosperity and Happiness. 
RGoB (Royal Government of Bhutan). (2008). Constitution of the kingdom of Bhutan. Thimphu, Bhutan: Constitution Drafting Committee.

RGoB, MoA (Royal Government of Bhutan, Ministry of Agriculture). (1995). LUPP Dzongkhag data sheets for Bhutan. Thimphu, Bhutan: Land Use Planning Project.

RGoB, MoAF (Royal Government of Bhutan, Ministry of Agriculture and Forests). (2010a). National forest policy of Bhutan 2010. Bhutan: Thimphu.

RGoB, MoAF (Royal Government of Bhutan, Ministry of Agriculture and Forests). (2010b). Bhutan renewable natural resources census 2009. Thimphu, Bhutan.

RGoB, MoAF (Royal Government of Bhutan, Ministry of Agriculture and Forests). (2012). Agriculture survey 2011, Vol. I. Dzongkhag level statistics. Thimphu, Bhutan.

Roder, W., Wangdi, K., Gyamtsho, P., Dorji, K. (2001). Feeding the herds: Improving fodder resources in Bhutan. Kathmandu, Nepal: ICIMOD. ISBN: 92-9115-409-1. http://books. icimod.org/index.php/search/publication/109

Samdup, T., Udo, H. M. J., Viets, T. C., \& van der Zijpp, A. J. (2013). Livestock intensification and use of natural resources in smallholder mixed farming systems of Bhutan. Livestock Research for Rural Development, 25(7), article 114.

SCBD (Secretariat of the Convention on Biological Diversity). (2001). The value of forest ecosystems.CBD Technical Series No. 4. Montreal, Canada.

Sharma, C. M., Khanduri, V. P., \& Ghildiyal, S. K. (2012). Reproductive ecology of male and female strobili and mating system in two different populations of pinus Roxburghii. Scientific World Journal, 2012, 1-13.

Tobgay, S. (2005). Small farmers and the food system in Bhutan. Thimphu, Bhutan: Royal Government of Bhutan, Ministry of Agriculture.

Tobgay, S., \& McCullough, E. (2008). Linking smallholder farmers in Bhutan with markets: The importance of access to roads. In E. McCullough, P. Pingali, \& K. Stamoulis (Eds.), Transformation of agri-food systems: Globalization, supply chains and smallholder farmers (pp. 259-278). London: Earthscan.

UNEP (United Nations Environment Programme). (2009). Strategizing climate change for Bhutan. National Environment Commission, Royal Government of Bhutan and UNEP Report. www. rrcap.unep.org/nsds/uploadedfiles/file/bhutan.pdf

Vanlauwe, B., \& Giller, K. E. (2006). Popular myths around soil fertility management in Sub-Saharan Africa. Agriculture, Ecosystem and Environment, 116, 34-46.

Wangdi, K. (2006). Country pasture/forage resource profiles for Bhutan. Thimphu, Bhutan: FAO. www.fao.org/ag/AGP/agpc/doc/Proceedings/Tapafon02/tapafon8.htm

Wangdi, K. (2012). Bhutan country pasture profile. www.fao.org/ag/agp/AGPC/doc/pasture/ forage.htm

Winslow, M., Sommer, S., Bigas, H., Martius, C., Vogt, J., Akhtar-Schuster, M., Thomas, R. (Eds.). (2011). Understanding desertification and land degradation trends. In Proceedings of the UNCCD First Scientific Conference, during the UNCCD Ninth Conference of Parties, Buenos Aires, Argentina. 22-24 Sept 2009. Luxembourg: Office for Official Publications of the European Communities. doi:10.2788/62563

WOCAT (World Overview of Conservation Approaches and Technologies). (2007). Where the land is greener: Case studies and analysis of soil and water conservation initiatives worldwide. www.wocat.net/fileadmin/user_upload/documents/Books/WOOK_PART1.pdf

Ziadat, F. M., Oweis, T., Al-Wadaey, A., Aw Hassan, A., Sakai, H., van der Zanden, E., et al. (2012). Soil conservation and water harvesting to improve community livelihoods and fight land degradation in the mountains of Syria. ICARDA working paper 9. Beirut, Lebanon: ICARDA.

Ziadat, F. M., \& Taimeh, A. Y. (2013). Effect of rainfall intensity, slope, land use and antecedent soil moisture on soil erosion in an arid environment. Land Degradation and Development, 24, 582-590. 